\title{
MORE GAIN, MORE PAIN: THE DEVELOPMENT OF INDONESIA'S ISLAMIC ECONOMY MOVEMENT (1980S-2012)
}

\section{Shofwan Al Banna Choiruzzad}

\section{Introduction}

In 2008, a television advertisement used to promote the Indonesian i-B (Islamic Banking) ${ }^{1}$ looked similar to an advertisement produced by its "conventional" (i.e., interest-based) counterparts.

The commercial opened with a scene of a businesswoman, without a veil, entering a bank. The following scenes that unfolded were: a husband cooking while his wife was busy at work; somebody stopping a quarrel between two bus passengers by giving them a pillow, thus allowing them to share the space comfortably; a Chineselooking businessman helping his driver push his broken-down car, and then sharing a drink from the same bottle; and a little girl playing basketball with a cool, sporty looking boy. There was no instance of a Muslim preacher or quotation from the

1 " $\mathrm{i}-\mathrm{B}$ " (Ai-Bi) is the common identifier for Islamic banking in Indonesia launched by the Central Bank of Indonesia, BI, on July 2, 2007. The fancy name was intentionally chosen to influence the audience and connect it with "modern" brands such as iPhone, iPod, and ibank, and thus build a modern image for Islamic banking services. 
Qur'an. The differentiation of Islamic banking from conventional banking was highlighted smoothly by illustrating the benefit of "sharing fairly" in all of the scenes. ${ }^{2}$

This commercial was interesting due to the fact that, not so long ago, in the late 1990s and even until early 2000, the first (and only) Islamic bank in Indonesia was still very fond of using religious passages in its marketing brochures, condemning interest as riba (usury), and threatening readers with divine punishment. ${ }^{3}$

Far deeper than a simple marketing gimmick, the TV commercial was a vivid illustration of how the Islamic banking industry and the wider Islamic economy project in Indonesia, at both the discursive and practical levels, had undergone significant change throughout its development. This paper will provide a comprehensive picture of the development of Indonesia's Islamic economy movement from its early stages until the present.

\section{The Islamic Economy Movement and Islamic Economy Project}

Before proceeding further, it is important to distinguish clearly between "Islamic banking" and the "Islamic economy movement." "Islamic banking" is a term used to refer to banking practices that, according to the Islamic economy movement, are conducted in accordance with Islamic law (shari'a). Our discussion understands the "Islamic economy movement" (gerakan ekonomi Islam) to encompass organized individuals, groups, or movements that call and struggle for the Islamization of the entire economic system.

In line with this definition, one leading platform for the Islamic economy movement in Indonesia, Masyarakat Ekonomi Syariah (MES, Islamic Economic Society/Al Ijtima'i lil Iqtishadi Al Islamiy), proudly proclaims that the vision of the association is to "establish a society that conducts all economic activities in accordance with Islamic rules" ${ }^{\prime 4}$ and frequently identifies itself as part of a larger entity called the Islamic economy movement (gerakan ekonomi Islam).

Proponents of the Islamic economy movement believe that the Islamic economic system is superior to other systems, such as socialism and capitalism. ${ }^{5}$ Robert Hefner observed that:

\footnotetext{
${ }^{2}$ One central difference between Islamic banking and interest-based banking is the prohibition against charging interest. Instead of interest, Islamic banking provides services based on the principle of profit sharing (bagi hasil). This explains why the value of "sharing fairly" was foregrounded as the main message of the advertisement.

${ }^{3}$ Interview with Aries Muftie, former Head of Operations and director, Bank Muamalat Indonesia, September 12, 2011. He also served as a chairman of MES (Masyarakat Ekonomi Syariah, Islamic Economic Society). Now, Aries Muftie is the chairman of ABSINDO (Asosiasi Baitul Maal Wat Tamwil seIndonesia, Association of Indonesian Islamic Cooperatives). Hermawan Kartajaya, founder and president of MarkPlus Inc. and a member of the Komite Perbankan Syariah (Islamic Banking Committee) in 2008-10, offered similar information when I interviewed him on August 11, 2011. Note: for a list of the acronyms appearing in this essay, see page 171.

${ }^{4}$ Anggaran Dasar Masyarakat Ekonomi Syariah (Articles of Association for an Islamic Economic Society), article 4.

${ }^{5}$ Umer Chapra, "What Is Islamic Economics?" in IDB Prize Winner Lecture Series 9 (Jeddah: IRTI, First Edition: 1996, Second Edition: 2001), p. 46.
} 
Islamic economics is ... a modern movement that asserts that Islamic traditions of law and organization provide a more just and equitable model for economic growth than do rival systems of Western capitalism and socialism. ${ }^{6}$

What exactly do people mean by the phrase "Islamic economy"? As noted above, usually, it is used to refer to all economic activities conducted in accord with shari'a; however, it is often difficult to determine a clear, general definition of what this means because there is a debate among Muslims themselves concerning which economic activities are in accordance with shari' $a$ and which are not. ${ }^{7}$ Thus, I prefer to use a more specific term and will discuss the "Islamic economy project," which refers to "all economic activities and related efforts that are established and promoted by that Islamic economy movement as part of their campaign to Islamize the economy." "Islamic banking" is part of this Islamic economy project.

One can trace various manifestations of the Islamic economy project internationally, such as the Islamization of banking and finance, the development of Islamic economics as a discipline (the Islamization of the science of economics), ${ }^{8}$ and the introduction of zakat (Islamic religious alms) as a redistribution policy in various countries.

We are witnessing the growth of this project. Over the last three decades, the number and size of Islamic banks and financial institutions have been growing rapidly worldwide. According to The Banker, shari'a-compliant assets crossed the US\$1,000 billion milestone in 2011 and are still increasing. Global Islamic banking assets have grown from USD $\$ 145$ billion in 2002 to USD\$1.086 trillion in 2011. ${ }^{9}$ Some non-Muslim majority countries, such as the United Kingdom, Thailand, and Singapore, are ranked among The Banker's top twenty-five countries in terms of the number of shari'a compliant assets. ${ }^{10}$ Since the First International Conference on Islamic Economics in

\footnotetext{
${ }^{6}$ Robert W. Hefner, "Islamic Economics and Global Capitalism," Society 44,1 (November/December 2006): 17. Hefner refers to the movement as "Islamic economics," while Islamic Banking and zakat are seen as the implementation thereof. Here, I define both "Islamic economics" and the practices of the Islamic economy to be manifestations of the broader Islamic economy project. These practices often develop simultaneously with, or precede, the formulation of academic theories outlining Islamic economics as science. Both are manifestations of the Islamization of the economic system.

${ }^{7}$ Until the 2000s, Indonesia's largest Muslim organization, Nahdlatul Ulama (NU), still accepted that Islamic scholars held different opinions concerning the prohibition of interest, which is a key factor in defining and justifying Islamic banking and other Islamic economy projects. NU criticized the issuance of fatwa number 1 / 2004 by Majelis Ulama Indonesia (MUI, The Indonesian Council of Islamic Scholars) on the prohibition of bank interest. See "NU Tolak Rencana Fatwa MUI yang Haramkan Bunga Bank" (NU Rejects Plan of the Indonesian Council of Islamic Scholars to Issue a Fatwa Prohibiting Bank Interest), November 10, 2003, at http: / / www.nu.or.id/ a,public-m,dinamic-s,detail-ids,1-id,858-lang,id-c,wartat,NU+Tolak + Rencana+Fatwa+MUI+yang+Haramkan+Bunga+Bank-.phpx, accessed on May 14, 2012.

${ }^{8}$ Thus, proponents of the Islamic economic movement consider "Islamic economics" to encompass both the economic system and the analysis of that system. See M. Anas Zarqa, Problems of Research in the Theory of Islamic Economics: Suggested Solutions (Jeddah: IRTI, 1986), p. 52.

${ }^{9}$ Melissa Hancock, "Islamic Finance's Growth Story Is Only Just a Beginning," The Banker, November 1, 2011, http:/ / www.thebanker.com / Markets / Islamic-Finance / Islamic-finance-s-growth-story-is-only-justbeginning, accessed May 12, 2012; and Joseph DiVanna, "Islamic Finance Roars Again," The Banker, November 1, 2011, http:/ / www.thebanker.com/ Markets/Islamic-Finance/Islamic-finance-roars-again, accessed May 12, 2012.

${ }^{10}$ Brian Caple and Joseph DiVanna, "Top Five Hundred Islamic Financial Institutions," The Banker, November 24, 2010, http: / / www.thebanker.com / Markets / Islamic-Finance/Top-500-Islamic-FinancialInstitutions2, accessed on May 12, 2012.
} 
Mecca (1976), many studies on Islamic economics have been published and academic institutions have offered Islamic economics in their curricula.

In Indonesia's context, the ISEO (Indonesia Shari'a Economic Outlook), published by the Center for Islamic Economics and Banking of the Faculty of Economics of the University of Indonesia, included the following sectors as part of the Islamic economy: 1) Islamic banking (perbankan syariah); 2) Islamic insurance and reinsurance (asuransi dan reasuransi syariah); 3 ) the Islamic capital market (pasar modal syariah); 4) the Islamic money market (pasar uang syariah); 5) Islamic microfinance (keuangan mikro syariah); 6) zakat (which involves the donation and distribution of non-obligatory religious almsinfaq and shodaqoh ${ }^{11}$-managed by zakat-management institutions); and 7) waqf $f^{12}$ (wakaf). ${ }^{13}$

While the initiatives of the Islamic economy movement are not limited to Islamic banking and finance, as we have discussed above, that particular field has been the "torchbearer" of the movement because of its relatively high profile. Compared to other initiatives, such as the development of Islamic economics as a distinct academic discipline, or the zakat project, Islamic banking is more visible to the broad public. Furthermore, banking and finance constitute a sector that is strongly regulated by the government. For these reasons, I will focus predominantly on the development of Islamic banking, without neglecting the development in other sectors.

\section{The Puzzle}

There are several works that already touched upon this issue. Robert Hefner, a longtime observer of Indonesian Islam, has discussed the political context surrounding the foundation of Indonesia's first Islamic Bank, Bank Muamalat Indonesia. ${ }^{14}$ Bachtiar Effendy wrote a critical overview on the development of Islamic economic institutions in Indonesia. ${ }^{15}$ Umar Juoro provided insights regarding the development of Islamic

\footnotetext{
${ }^{11}$ Shodaqoh refers to all alms-giving except the obligatory zakat. It must be noted, though, that the word "shodagoh" is sometimes used in the Qur'an to refer to zakat. The difference between infag and shodaqoh is not really clear and the terms are often used interchangeably, but infaq usually refers to monetary charity, while shodaqoh is not limited to cash exchanges. In Indonesia, the designation "Zakat-Infaq-Shodaqoh" (ZIS) is used to explain that the institution is managing all kinds of religious alms.

${ }^{12}$ Law Number 41/2004 on waqf defines "waqf" as "a legal act of a person (i.e., "waqif") to dedicate his/ her wealth or a portion of it to be used/disbursed for religious projects (e.g., Masjid) or for the benefit of the broader public (e.g., school) in an unlimited or limited time." See http:// bwi.or.id/index.php?option= com_content\&view=article\&id=58\&Itemid=54\&lang=in, accessed March 9, 2013.

${ }^{13}$ Pusat Ekonomi dan Bisnis Syariah Fakultas Ekonomi Universitas Indonesia (PEBS FEUI), Indonesia's Shari'ah Economic Outlook 2011 (Jakarta: Lembaga Penerbit Fakultas Ekonomi Universitas Indonesia, 2011), pp. 1-143. PEBS FEUI, established January 29, 2007, in Depok, is regarded as a leading academic institution for Indonesia's Islamic economy movement.

${ }^{14}$ Robert W. Hefner, "Islamizing Capitalism: On the Founding of Indonesia's First Islamic Bank," in Shari'a and Politics in Modern Indonesia, ed. Arskal Salim and Azyumardi Azra (Singapore: ISEAS, 2003), pp. 14867. The aforementioned article is a reprint of Robert W. Hefner, "Islamizing Capitalism, On the Founding of Indonesia's First Islamic Bank" in Toward a New Paradigm: Recent Developments in Indonesian Islamic Thought, ed. Mark R. Woodward (Tempe, AZ: Arizona State University, 1996), pp. 291-322.

${ }^{15}$ Bachtiar Effendy, "Islamic Economic Institutions in Indonesia: A Religio-Political Perspective," in Islam in Southeast Asia: Political, Social and Strategic Challenges for the Twenty-First Century, ed. K. S. Nathan and Mohammad Hashim Kamali (Singapore: Institute of Southeast Asian Studies, 2005), pp. 64-81.
} 
banking in Indonesia, particularly after the Asian Crisis of 1997-98. ${ }^{16}$ Minako Sakai observed the historical development and the impacts resulting from Baitul Maal wat Tamwil (BMT), an Indonesian-style cooperative that combines an intermediary institution and religious alms management institution (Sakai used the term "Islamic savings and credit cooperative"), and discusses its relation to the concept of Islamic economics. ${ }^{17}$ Thomas B. Pepinsky has analyzed the risk of developing an Islamic financial system alongside the "conventional" financial system in a multicultural Indonesia. ${ }^{18}$

In general, these academic studies have focused on particular aspects and specific segments in the historical development of the Islamic economy movement in Indonesia. They mostly examine practical symptoms or manifestations of the movement over a short period of time, such as the development of Islamic banks and financial institutions, or BMTs, and they tend to focus less on the Islamic economy movement, itself, as a movement, which gave birth to these institutions.

It is remarkable that, despite the growing number of works on the Islamic economy in Indonesia, there have been relatively few attempts to grasp a comprehensive history of Indonesia's Islamic economy movement and the socio-political dynamics surrounding it. Two decades after the birth of Indonesia's first Islamic bank, Bank Muamalat Indonesia, in 1991, and more than three decades after the birth of Indonesia's Islamic economy movement in the 1980s, it is time to examine it in a comprehensive manner. This paper has been written as an attempt to bridge this gap.

In order to do so, the following questions should be asked: How has Indonesia's Islamic economy movement developed since its birth in the 1980s? What are the changes and the continuities? What are the socio-political factors that have shaped the growth of the Islamic economy movement? Who are the driving forces behind the growth of the Islamic economy in Indonesia? What are their motivations? In what way has the state played a role in the development of the Islamic economy project, and how has the state influenced the Islamic economy movement?

\section{The Birth of a Movement}

On October 31, 2010, the book Membumikan Ekonomi Islam (roughly translated as Realizing the Islamic Economy) was launched at Bogor Agricultural University's International Conference Center (ICC). Many of the current prominent figures in Indonesia's Islamic economy movement were involved in the preparation of the book

\footnotetext{
${ }^{16}$ Umar Juoro, "The Development of Islamic Banking in the Post-Crisis Indonesian Economy," in Expressing Islam: Religious Life and Politics in Indonesia, ed. Greg Fealy and Sally White (Singapore: Institute of Southeast Asian Studies, 2008), pp. 229-50.

${ }^{17}$ Minako Sakai, "Community Development through Islamic Microfinance: Serving the Financial Needs of the Poor in a Viable Way," in Expressing Islam, ed. Fealy and White, pp. 267-85; Minako Sakai, "Growing Together in Partnership: Women's Views of the Business Practices of Islamic Savings and Credit Cooperative (Baitul Maal Wat Tamwil) in Central Java, Indonesia," Women's Studies International Forum 33 (2010): 412-21.

${ }^{18}$ Thomas B. Pepinsky, "Islamic Finance in Multicultural Indonesia," in Towards an Inclusive Democratic Indonesian Society, ed. Frank Dhont, Kevin W. Fogg, and Mason C. Hoadley (Yogyakarta: Atma Jaya University Press, 2009), pp. 55-82.
} 
and the event. Mulya E. Siregar, Director of the Directorate of Islamic Banking in Indonesia's Central Bank (Bank Indonesia, or BI), wrote a section of the preface, praising the author as a "teacher of Indonesia's Islamic economy activists." There was also a section in the book consisting of testimonies from leading figures in the Indonesian Society for the Islamic Economy, including Adiwarman Karim, ${ }^{19}$ Syafi' $i$ Antonio, ${ }^{20}$ and Syakir Sulla, ${ }^{21}$ in which the author was applauded as "the mastermind" of Indonesia's Islamic economy. The publication of the book itself was sponsored by Bank Muamalat Indonesia. Many directors and advocates involved in Islamic banks, Islamic financial institutions, and zakat organizations attended this event and came to pay their respects to one of the pioneers of the Islamic economy movement in Indonesia.

Ahmad Muflih Saefuddin wrote this book, ${ }^{22}$ a mixture of his economic thinking and his personal reflections on the development of the Islamic economy movement in Indonesia from its beginnings in the 1980s. The book was launched on his seventieth birthday. ${ }^{23}$ The publication itself, the celebration, and the presence of so many of the leading actors in Indonesia's Islamic economy at the event illustrated the important role that had been played by Saefuddin during the formative years of the movement.

\section{The Emergence and Development of the Islamic Economy Movement in the 1980s}

During the late colonial period, an Islam-inspired movement, Sarekat Islam (SI, Islamic League), founded in 1912, was considered to be the dominant nationalist

\footnotetext{
${ }^{19}$ Adiwarman Karim is the founder and President Director of Karim Business Consulting, a leading consultant who plays an important role in helping to establish many Islamic financial institutions in Indonesia, and one of the chairmen of the Indonesian Society for Islamic Economy. Karim received his MBA from Belgium's European University and a Master of Arts in Economics and Economic Policy from Boston University, in the United States. He joined the first Islamic bank in Indonesia, Bank Muamalat Indonesia, in 1992, and later was vice president of the Muamalat Institute and the main branch head of the Bank Muamalat Indonesia in Bandung, until 2001.

${ }^{20}$ Syafi'i Antonio is a leading Islamic economist in Indonesia. He graduated from Jordan University (bachelor's degree 1990), International Islamic University (IIU), Malaysia (masters degree in Islamic Economics, 1992), and the University of Melbourne (doctorate in banking and microfinance, 2004). After graduating from IIU, he joined Indonesia's first Islamic Bank, the Bank Muamalat Indonesia (BMI). He was also involved in the establishment of Indonesia's first Islamic insurance company, Takaful, in 1994. Following his resignation from BMI, he established Tazkia Group. With his team in Tazkia Consulting, Antonio has helped with the establishment of many Islamic financial institutions in Indonesia. He is the chairman of Tazkia University College of Islamic Economics (STEI TAZKIA). Together with Adiwarman Karim, currently he is one of the most popular personalities in the Islamic economy movement; see http: / / www.syafiiantonio.com/index.php?content=isi\&id=69, accessed March 9, 2013.

${ }^{21}$ Secretary General of MES.

${ }^{22}$ A. M. Saefuddin, Membumikan Ekonomi Syariah (Jakarta: PPA Consultants, 2011). Ahmad Muflih Saefudin (born October 1, 1940) is a leading figure in Indonesia's Islamic economy movement, acknowledged as the initiator of the movement, and often considered the "teacher" of the younger generation of Islamic economists. He is also recognized as a prominent Muslim intellectual and politician He served as Ibnu Chaldun University Rector (1983-86), parliament member in the Islamic United Development Party (Partai Persatuan Pembangunan, PPP) (1992-2004), and Minister of Food and Horticulture (1998-99).

23" Ultah ke-70, A. M. Saefuddin Luncurkan Empat Buku," at http:/ / www.radarbogor.co.id/index.php?id=63488\&rbi=berita.detail, accessed October 5, 2011.
} 
organization in the colonial Dutch East Indies. ${ }^{24}$ The origins of the organization could be traced back to a trade union named Sarekat Dagang Islam (Islamic Trade Union), established in 1905 with the aim to unite native traders to resist domination by Chinese traders who had been favored by Dutch colonial policies. Historically, therefore, economic considerations played a role in political Islam, in Indonesia, since the early twentieth century. However, the discourse advocating a distinct "Islamic economy" and a campaign to establish an Islamic economic system was nowhere to be found in public discourse until the late 1970s or early 1980s, except for some excerpts from speeches by ulama or Muslim organizations, and there were no serious organized efforts to realize such an economy. ${ }^{25}$

In 1976, A. M. Saefuddin was among the five Indonesians who attended the First International Conference on Islamic Economics in Mecca. He received the invitation from Mohammad Natsir, a charismatic leader of Masyumi (an Islamic party that was dissolved and banned during Sukarno's "guided democracy" period and was prevented from resurfacing by Suharto, during his move to consolidate power in the 1960s). ${ }^{26}$ Nothing really special came about after Saefuddin's return from the conference, but he had become aware that Islamic economics was developing into an academic field and had stimulated practical efforts in various countries. He then worked with the World Bank as its advisor for agriculture within Bank Indonesia from 1978-82. At around the same time, he established the Center for Agribusiness Development (Pusat Pengembangan Agribisnis, or PPA) with Amin Aziz, Abdillah Thoha, Adi Sasono, and Dawam Raharjo, men who would later come to be known as leading figures who contributed to the rise of the Ikatan Cendekiawan Muslim Indonesia (ICMI, Association of Indonesian Muslim Intellectuals), in the 1990s. ${ }^{27}$ Aziz was particularly important in the development of the Islamic economy movement as he is considered the man behind the establishment of Indonesia's first Islamic bank. ${ }^{28}$

\footnotetext{
${ }^{24}$ For the role of SI in the rise of Indonesia's nationalism, see George McTurnan Kahin, Nationalism and Revolution in Indonesia (Ithaca, NY: Cornell University Press, 1952). See also Ruth McVey, "Faith as the Outsider: Islam in Indonesian Politics," in Islam in the Political Process, ed. James Piscatori (Cambridge: Cambridge University Press, 1983).

${ }^{25}$ It should be noted, though, that Indonesians evidenced an uneasiness in relying on banks that charged interest long before the Islamic economy movement finally organized an effort to realize Indonesia's first Islamic bank. For example, the chairman of Muhammadiyah during 1937-44 expressed his opinion that using the service of an interest-based bank was only acceptable in case of an emergency. A similar uneasiness was also displayed by members of another large Muslim organization, Nahdlatul Ulama. Several publications on Islamic views concerning economic matters addressed this same issue. A. M. Saefuddin, for example, recalled that he had read a book titled Ekonomi Nurani when he was a teenager. He forgot the exact title of the book, and the name of the author, whom he was sure was an Indonesian, but he remembered that it contained some Islamic views on economic matters. Nevertheless, there was no organized campaign to Islamize the economy. Interview with A. M. Saefuddin, September 16, 2011.

${ }^{26}$ Ibid.

${ }^{27}$ ICMI was founded in 1990 . The first chairman was the Indonesian Secretary of Research and Technology at the time: B. J. Habibie. The establishment of ICMI was one important milestone marking the political shift of President Suharto, who had grown more open to the concerns of Muslim groups since the early 1990s. ICMI was very influential in the 1990s. In jokes, ICMI was often translated as "Ikatan Calon Menteri Indonesia" (Indonesia's Association of Minister Candidates).

${ }^{2 s}$ Interview with Saefuddin, September 16, 2011. This judgment was confirmed by a statement in ICMI's book, Zaim Uchrowi and Usman Ks, ICMI Bergerak: Lintasan 10 Tahun Ikatan Cendekiawan Muslim seIndonesia, (Jakarta: Republika, 2000), pp. 92-93.
} 
Working with the World Bank and the Bank Indonesia gave Saefuddin firsthand experience at the heart of Indonesia's development policies. He was disappointed because he felt that these policies were only benefiting a few people while neglecting the poor. According to him, "with this system, the money will be accumulated in a few hands. ${ }^{29}$ His dissatisfaction with the entire system prompted him to remember and reconsider the Islamic economic precepts he had encountered and heard discussed at the 1976 conference. In the early 1980s, he initiated a campaign to develop the Islamic economy. He called upon other Indonesian participants in the 1976 conference to join his effort, but there was no positive response. Some replied that they were "too busy," while others considered the notion of an Islamic economy to be a vague concept.

Saefuddin then resorted to the PPA, which was actually focusing on the social economy of agriculture, and he used his position as a lecturer in the Bogor Institute of Agriculture to introduce the idea of the Islamic economy to his students. Adiwarman Karim was among the first students who were influenced by these proposals, tactically incorporated in Saefuddin's class on "Marketing Management." ${ }^{30}$ Saefuddin and his fellows in the PPA also disseminated the idea through various seminars, discussions, articles, and religious events using their network of Islamic organizations and activists.

During this period, the idea of an Islamic economy was often mixed up with the idea of a "people's economy," or ekonomi kerakyatan (some considered them synonymous), because it criticized the development policies of Suharto, which neglected the poor and benefited only a few. The central motive of an Islamic economy is, according to Saefuddin, "to prevent the accumulation of capital in the hands of few people and to ensure the wealth and happiness of all segments of society." ${ }^{31}$

However, the responses from Muslim organizations to these proposals were not always positive. During this period, Islamic scholars in Nahdlatul Ulama, Indonesia's largest Muslim organization, were debating the advantages and disadvantages of banks that charge interest, a practice criticized by the Islamic economy movement as usury and the root of exploitation. A significant number of NU members did not consider interest to be usury (riba), and thus argued that it should be permitted. ${ }^{32}$ Abdurrahman Wahid, NU's executive chairman from 1984 to 1999, criticized the idea of an Islamic economy as "outdated" and founded-together with the Summa Bank,

\footnotetext{
${ }^{29}$ Interview with A. M. Saefuddin, September 16, 2011.

${ }^{30}$ Saefuddin, Membumikan Ekonomi Islam, p. 318.

${ }^{31}$ Interview with A. M. Saefuddin, September 16, 2011. The idea is still popular among early Islamic economy activists.

${ }^{32}$ However, the NU also studied the possibility of implementing the Islamic economy, including the institution of an Islamic banking system. See Muhammad Ali, "Islam and Economic Development in New Order Indonesia (1967-1998)," East-West Center Working Papers: International Graduate Student Conference Series, No. 12, 2004, pp. 20-22. In 1982, NU's Bahsul Masa'il forum in Bandar Lampung raised the issue of bank interest and even touched upon the issue of an Islamic bank. As a result, there were three different viewpoints on the issue of interest: first, the view that interest is usury and thus prohibited (haram); second, the view that interest is not usury and thus it is allowed (halal); and third, the view that the interpretation is in doubt (syubhat) because of the existence of differing viewpoints. The forum itself recommended that the NU establish a bank that operates without charging interest. However, Abdurrahman Wahid, its executive chairman from 1984 until 1999, strongly opposed the development of an Islamic bank.
} 
owned by the Suryajaya family, a Chinese-Indonesian conglomerate, ${ }^{33}$-a joint-venture bank (NU-Summa, with its operations based on interest).

Some of the leading figures of Political Islam also criticized these economic proposals. Syafruddin Prawiranegara, a leading Muslim politician who was once a leader of Masyumi and was the president of the Emergency Government of the Republic of Indonesia (Pemerintah Darurat Republik Indonesia), challenged Saefuddin's ideas and asserted that to charge or pay interest must be distinguished from usury and permitted for Muslims. ${ }^{34}$

The government was also unhappy with Saefuddin's campaign for an Islamic economy, considering his proposal a threat to economic stability. Saefuddin recalled government officials warning him, "If Muslims take your argument against interest seriously, there will be a big rush, starting a crisis that endangers our economic stability." A similar warning was issued by his alma mater, Bogor Institute of Agriculture, which warned that he would be fired from his position as a lecturer because of his activism. ${ }^{35}$

Despite the criticism, the Islamic economy movement soon found its supporters among university students and some Muslim organizations. This is understandable, because, during this period, as the government sought to suppress Political Islam, many Muslim activists resorted to Islamic activities on campus. Some sympathizers disseminated the idea within the classroom, wrote articles and academic papers, and held discussions and study groups in universities. During the 1980s to the early 1990s, various informal discussions on the Islamic economy sprang up in notable universities in Bogor, Bandung, Jakarta, Yogyakarta, Surabaya, and other large Indonesian cities, organized by Muslim youth organizations based in various campus mosques. ${ }^{36}$ Among these campus-based organizations, Bandung Institute of Technology's Salman Mosque Youth (Remaja Masjid Salman ITB) was considered the trendsetter. ${ }^{37}$ In the latter stages, especially in the 2000s, some former activists of these student organizations who chose an academic career successfully established departments and curricula focused on Islamic economics within their respective universities.

The first National Conference on the Islamic Economy, which was held at Bandung Islamic University (Universitas Islam Bandung, UNISBA) in 1983, was an important factor in adding impetus to the movement. While the conference was not held at the

\footnotetext{
${ }^{33}$ Adam Schwarz, A Nation in Waiting: Indonesia's Search for Stability (Singapore: Talisman, 2004), pp. 18889. This move was, in fact, initiated and advocated by Abdurrahman Wahid rather than the NU. Later, even as Islamic banking was expanding, in part thanks to support from the government, the NU-Summa joint venture bank went bankrupt. The post-Wahid leadership of the NU became more open to the idea of an Islamic economy.

${ }^{34}$ Interview with A. M. Saefuddin, September 16, 2011. Syafruddin Prawiranegara, Ekonomi dan Keuangan: Makna Ekonomi Islam (Jakarta: CV Masagung, 1988), p. 290.

${ }^{35}$ Interview with A. M. Saefuddin, September 16, 2011.

${ }^{36}$ Author's interviews with Syamsoe Badaruddin and Yan Orgianus, August 8, 2011. Both were active in the early stage of the Islamic economy movement in Bandung in the 1980-90s and now are still involved in the MES. The same information was also acquired from an interview with Yusuf Wibisono and Banu Muhammad. Both are faculty members of University of Indonesia's Faculty of Economy and were actively involved in these discussion groups in University of Indonesia, August 12, 2011.

${ }^{37}$ Interviews with Syamsoe Badaruddin and Yan Orgianus, August 8, 2011.
} 
Bandung Institute of Technology (ITB), ITB's Salman Mosque Youth organization played an important role in its organization, since the idea for the conference came from Yusuf Amir Faisal, a Salman Mosque Youth activist. The event was held at UNISBA because the rector, Professor Muttaqien, was very supportive of the idea and the movement. ${ }^{38}$ Prominent figures who attended this event included Saefuddin, Fuad Amsyari (economist), Gunawan Muhammad (economist), ${ }^{39}$ Halide (economist from Hasanuddin University), ${ }^{40}$ and Dawam Raharjo. ${ }^{41}$

Following the Bandung Conference, experiments that had been proposed to initiate an Islamic economy were put into practice. A group of students established BaitutTamwil (House of Finance) Teknosa in 1984. This institution operated on the basis of the principles key to Islamic banking and finance, most notably by operating according to a concept of risk-and-profit-sharing instead of interest. Acting as an antithesis to the interest-based banks, which are often unfriendly to the poor, this institution focused on providing financial services to the poor. Another important experiment was Koperasi Ridho Gusti (the Lord's Blessings Cooperatives), established in Jakarta. Both initiatives were precedents organized by the Baitul Maal Wat Tamwil (Islamic Savings and Credit Cooperative), which flourished later in the 1990s. Despite those developments, the scale and impact of the Islamic economy movement was still very limited. The first Islamic bank was not established until the state changed its stance toward the Islamic economy in the late 1980s and early 1990s, following dynamic changes within the Suharto regime.

\section{Why the 1980s?}

What are the enabling factors behind the birth and growth of the Islamic economy movement among Indonesian Muslim communities in the 1980s? The first factor was the rise of this movement on a global level. During the 1970s, the call for establishing Islamic economies in a number of countries found global momentum. This period was marked by the establishment of the Islamic Development Bank (1973), and the birth of many new Islamic banks in various countries (among them were: Dubai Islamic Bank, 1975; Islamic Commercial Bank of Abu Dhabi, 1977; Faisal Islamic Banks, 1977), as well as the organization of the First International Conference on Islamic Economics (1976), which some participants from Indonesia, including Saefuddin, attended. In one of Indonesia's neighboring countries, Malaysia, an international Islamic bank named Darul Mal al-Islami (DMI) was established in 1981. Yet it would not be accurate to see the birth of Indonesia's Islamic economy movement as merely the result of a proliferation of a certain global discourse. A more complete explanation for the birth

\footnotetext{
${ }^{38}$ According to Syamsoe Badaruddin, in the late 1970s, Professor Muttaqien of UNISBA had already proposed the establishment of an Islamic bank to the government. He said that he received no response from the government, which, according to Syamsoe, was controlled by an "anti-Muslim power." Interview with Syamsoe Badaruddin, August 8, 2011.

${ }^{39}$ An economist. Not to be confused with the prominent essayist and former editor of Tempo Magazine.

${ }^{40}$ Professor Halide is also regarded by the Islamic economy movement as one of its pioneers because of his involvement, as an Indonesian economist, in the establishment of the Islamic Development Bank.

${ }^{41}$ Interview with Syamsoe Badaruddin and Yan Orgianus, August 8, 2011.
} 
and growth of the Islamic economy movement in Indonesia must be sought at home, within the socio-political dynamics of Indonesia from the 1970s to 1980s.

\section{Depoliticization of Islam}

After claiming the presidency in 1967, Suharto quickly consolidated his power and worked to prevent the rise of any political opposition. The army general and his friends introduced the notion that the "extreme left" (ekstrim kiri, or eki) and "extreme right" (ekstrim kanan, or eka) posed a "latent danger" for the nation. ${ }^{42}$ Citing the need for political stability to encourage economic development, the New Order government conducted a "depoliticization" project aimed at Muslim groups.

The project was reflected in policies such as forcing Islamic parties to merge into a single party (1973), ${ }^{43}$ introducing a national marriage bill in order to "unify" the Indonesian marriage law (1973), ${ }^{44}$ establishing MUI (Majelis Ulama Indonesia, the Indonesian Council of Religious Scholars) in 1975 as a corporatist body used to issue religious decrees (fatwa) for supporting "development policies," ${ }^{45}$ establishing Penataran Pancasila (Pancasila Training) as an obligatory subject in the school curriculum (1978), and conducting bloody crackdowns against "radical" Muslim groups $(1976,1981,1984)$. These policies seemed to have proven successful in the late 1970 s and early 1980s. Islam and Muslim groups were deterred from becoming challengers in the political arena and even dissuaded from entering it. For many Muslim activists, Suharto's policies marked a "dead end" for Political Islam.

Yet, in response to these restrictions, various streams of political Islam were flowing out, some of them underground, to seek a way around this "dead end." Some proposed "reformulating the theological basis of political Islam" to bridge the gap between Islam and the state and make it possible for Muslims to enter the state's bureaucracy. ${ }^{46}$ Among these activists, many still believed that Islam should play an important role in managing the society. However, most did not have the courage or

\footnotetext{
${ }^{42} \mathrm{~S}$. Yunanto et al., Militant Islamic Movements in Indonesia and Southeast Asia (Jakarta: The RIDEP Institute and Friedrich Ebert Stiftung, 2003), p. 7.

${ }^{43}$ Islamic parties merged to form the PPP (Partai Persatuan Pembangunan, United Development Party). Christian and secular parties were forced to merge into PDI (Partai Demokrasi Indonesia, Democratic Party of Indonesia). Suharto established the government party, Golkar (Golongan Karya, or Functional Groups), which was expected to dominate the parliament.

${ }^{44}$ Mark Cammack,"Islamic Law in Indonesia's New Order," ICLO 38 (1989): 53-73.

${ }^{45}$ The Suharto regime created MUI to issue religious decrees (fatwa) for supporting "development policies" (for example, the fatwa justifying state-sponsored sports gambling or support for contraception).

${ }^{46}$ For details, see Bachtiar Effendy, Islam and the State in Indonesia (Singapore: Institute of South East Asian Studies, 2003). According to Bachtiar Effendy, the crisis of political Islam led to the emergence of "the new Islamic intellectualism." This movement was an attempt at "reformulating the theological basis of political Islam" and "redefining the socio-political goals of political Islam" in order to bridge the gap between Islam and the state. According to Effendy, there were three sub-streams of this movement: (1) the theological reform stream which called for desacralization, reactualization, and nativization of Islam; (2) the bureaucratic/political reform stream, which believed that the relationship between political Islam and the state could be better if Muslim activists started to be directly involved in the politics and the state's bureaucracy; and (3) the social transformation stream, which argued that the agenda of political Islam should be broadened - it must not limit itself to seeking influence on the state, but must also try to strengthen the people and civil society (this group started to build Non-Governmental Organizations working to empower Muslim communities throughout the nation).
} 
power to challenge the regime openly in the political arena. The majority of Muslim activists were eager for a change, but frustrated, and potentially ready to support any movement looking for social change by taking Islam as its core inspiration. When the discourse of the Islamic economy was introduced in the early 1980s, they quickly responded to it.

During this period, while it was true that the government disliked the movement and even issued some warnings to its activists, the regime did not see the Islamic economy movement as a serious political threat and so exerted little effort to quash it. Thus, the movement gained popularity among activists who looked for an Islamic platform from which they could advocate social reform without directly provoking the government. The movement was "heroic" enough to be appealing, and at the same time also "safe" enough.

\section{Perceived Economic Marginalization of Muslims}

The Islamic economy movement in Indonesia gained supporters among those who felt that Muslims had been economically marginalized. While not all of the early supporters understood the theories of Islamic economics that were introduced by the movement, quite a few found that many of the arguments clearly resonated with their perceptions of the economy. The powerful message was that the current economic system had unfairly benefited a small part of the society while neglecting the majority.

For many early sympathizers of the movement, the domination of Chinese Indonesians in the economy was seen as the proof of these inequities. Despite their demographic size (2.5 percent to 4 percent of the Indonesian population), they ran the economy. ${ }^{47}$ Chinese Indonesians owned 163 of 200 of Indonesia's top business groups (1989) and at least 80 percent of the 162 companies listed on the Jakarta Stock Exchange (1993). ${ }^{48}$

Of course, Chinese dominance was not new because the ethnic Chinese had dominated the economy since the colonial period. However, the New Order's policy of inviting foreign investments had benefited the Chinese Indonesians who were more ready to adapt to the new economic environment and possessed more capital. ${ }^{49}$ Furthermore, many Indonesians resented the fact that the Chinese obtained special privileges from the government by forging a close alliance with the New Order's political elites, which gave birth to the term cukong, denoting a relationship between a Chinese (who knew how to raise money) and Indonesian officials (who provided protection and influence). These connections gave the Indonesian Chinese various privileges: tax breaks, state bank funding, access to import and trading licenses, introduction to foreign investors, and freedom from harassment. For example, the joint ventures between Toyota and William Suryajaya and between Matsushita and Thajeb

\footnotetext{
${ }^{47}$ See Robert W. Hefner, "Islamizing Capitalism," p. 294. See also Muhammad Ali, “Islam and Economic Development in New Order's Indonesia," p. 17.

${ }^{48}$ Adam Schwarz, A Nation in Waiting, pp. 108-9.

${ }^{49}$ Howard Dick et al., The Emergence of A National Economy: An Economic History of Indonesia, 1800-2000 (Sydney: Allen \& Unwin, 2002), p. 141.
} 
Gobel (both Suryajaya and Gobel were Chinese Indonesians) were possible through the intervention of Suharto's close aide, Sujono Humardani. ${ }^{50}$

The economic policies of the Suharto government were seen as beneficial to the already rich Chinese conglomerates, but destructive for the Muslim majority. As one Muslim figure summarized:

In terms of the economy, they [Muslims] were marginalized in every sector ... Conglomerates with government facilities emerged everywhere, together with the death of small businesses, many of them run by santri [devout Muslims] ... From time to time, we hear news of the evictions of poor people. ${ }^{51}$

The resentment against Chinese domination was strong among non-Chinese Indonesians during the 1970 s and 1980s. This sentiment grew more powerful over time, creating a sense of danger among Muslim groups because, in their view, Suharto was surrounded by non-Muslims, such as L. B. Murdani ${ }^{52}$ from the military, and the technocrats Radius Prawiro, ${ }^{53} \mathrm{~J}$. B. Sumarlin, ${ }^{54}$ and Adrianus Mooy. ${ }^{55}$ Moreover, Suharto's unofficial think tank for development policies was the CSIS (Center for Strategic and International Studies), established in 1971 and run mostly by Chinese and Catholics. ${ }^{56}$ Against this backdrop, one popular theory was that widespread economic inequality, which trapped the majority of the population (i.e., Muslims) in poverty, was intentionally "designed" by an "Anti-Islam alliance" of military elites, technocrats, and Chinese businessmen. In religious meetings, many preachers joked that CSIS was

${ }^{50}$ Adam Schwarz, A Nation in Waiting, pp. 107-8.

${ }^{51}$ Tamsil Linrung, ed., ICMI: Beberapa Catatan Kritis (Jakarta: Amanah Putera Nusantara, 1995), pp. 41, 71. Also quoted in ICMI, 20 Tahun ICMI: Melanjutkan Long March di Milenium ke-21 (Jakarta: ICMI, 2010), p. 24. "Milenium ke-21" ("21st Millenium") probably meant "Twenty-First Century."

${ }^{52}$ Leonardus Bernardus Murdani was a powerful figure in Indonesia's military. He served as the Minister of Defense from 1983 to 1988 . He was involved in the infamous counter-terrorism operation in the 1981 Woyla hijacking. Because of this event (which many Muslim activists believed was part of a military conspiracy designed to strengthen the authoritarian regime's power) and several other events (including the bloody Tanjung Priok tragedy in 1984), Murdani was viewed as one of the archenemies of Islam by many Muslim activists, particularly those with a political orientation. Abdurrahman Wahid, the leader of Nahdlatul Ulama, Indonesia's largest Islamic organization, which tended to be critical of Political Islam, was close to Murdani. For a detailed account of the alliance between Murdani and Wahid, see Douglas E. Ramage, Politics in Indonesia: Democracy, Islam, and the Ideology of Tolerance (London: Routledge, 1995).

${ }^{53}$ Radius Prawiro was a powerful economist responsible for economic policies during Suharto's era. He served as the governor of Indonesia's Central Bank (1966-73), governor of the International Monetary Fund for Indonesia and vice governor of the Asia Development Bank for Indonesia (1967-71), chairman of the Governor's Council of the International Bank for Reconstruction and Development (1971-73), minister of Trade (1973-83), minister of of Finance (1983-88), and coordinating Minister for the Economy, Finance, Industry, and Development (1988-93).

${ }^{54}$ Johannes Baptista Sumarlin served as the Minister for the State Apparatuses (Menteri Negara Penertiban Aparatur Negara), the vice chairman of the National Development Planning Board (Badan Perencanaan Pembangunan Nasional, BAPPENAS), the head of Stabilization Operation (Operasi Penertiban, Opstib) in 1973-83, the minister for National Development Planning and the head of BAPPENAS in 1983-88, and minister of Finance in 1988-93.

${ }^{55}$ Indonesia's first Islamic Bank, Bank Muamalat Indonesia, was established in 1991, when Adrianus Mooy served as governor of Indonesia's Central Bank (1988-93). At first, many of Muamalat's founders were pessimistic about the likelihood that they would be allowed to establish an Islamic bank with Mooy at the head of the Central Bank.

${ }^{56}$ Amin Azis as quoted in Zaim Uchrowi and Usman Ks, ICMI Bergerak: Lintasan 10 Tahun Ikatan Cendekiawan Muslim se-Indonesia, p. 96. 
an acronym for "Cina Senang, Islam/Indonesia Susah" (Chinese are happy; Islam/Indonesia is in misery). However, it should be noted that there were also Muslims among the ranks of the economic technocrats, such as Ali Wardhana and Muhammad Sadli. Nevertheless, they were often accused of being part of the same conspiracy due to the strong perception that unjust economic policies were aimed against Muslims.

The focus on an allegedly unjust economic system that characterized the early discourse of the Islamic economy movement connected the movement with those who shared their concerns. For them, "Islamic economy" (ekonomi Islam) was synonymous with the "people/populist economy" (ekonomi kerakyatan), as noted above, or at least they saw the two as inseparable. According to Mulya E. Siregar, currently the director of the Directorate of Islamic Banking at Indonesia's Central Bank, the activists of the Islamic economy movement often used the term the "people's economy" to convey the messages of the "Islamic economy." ${ }^{57}$

Later, when Habibie was able to implement his economic vision through ICMI, favoring the development of high-technology industries with strong nationalist rhetoric, these three discourses blended together. Economic nationalism, the people economy, and the Islamic economy were inseparable, and all these phrases were featured as the keywords of ICMI's economic discourse. ${ }^{58}$

The Absence of an Economic Discourse for Muslim Opposition against the New Order's Economic Policy

Economic development, directed by a group of economists, was at the core of New Order policies, at least until Habibie's rise in the 1990s. The centrality of the economic technocrats in the government made the policies difficult to criticize. While the iron fist of the military insured the implementation of the policies, the concepts themselves were defended by economic theories that were coming from economists linked with global financial institutions.

For Muslim activists, the appeal of the Islamic economy movement lies in its potential to connect various criticisms of government economic policies into an integrated framework. They realized that loose criticism, unattached to any framework, only works well in rallies, but not in debates. To oppose the development policies that were perceived as unfair, and provide alternative strategies, one must have a framework to understand the economy. As Saefuddin stated:

We know that banks are favoring the rich over the poor, protecting the money of the rich and neglecting the fate of the poor, and thus creating larger and larger gaps in the economy ... to change that, we need a clear framework to change the policies. ${ }^{59}$

While those close to the left could rely on traditions and established theories to guide their movement (i.e., Marxist economic thinking), Muslim groups had no such

\footnotetext{
${ }^{57}$ The comment of Mulya E. Siregar recorded in Saefuddin, Membumikan Ekonomi Islam, p. 320.

${ }^{58} \mathrm{ICMI}$ and its role will be discussed further in the next sections.

${ }^{59}$ Interview with A.M. Saefuddin, September 16, 2011.
} 
theoretical structure. The Islamic economy movement filled this gap by providing a discourse that seemed to offer a framework to explain the economy and provide an alternative. "It was the idealism of the Islamic economy (which stresses the importance of justice) which made me curious and want to understand it further," Adiwarman Karim recalled. ${ }^{60}$

\section{The Rise of a Religious Muslim Middle Class}

While Islam and Muslim groups were successfully forced out from the political arena in the late 1970s and even deterred from entering it, the presence of Islam in Indonesian society was getting stronger. The jilbab (scarf for Muslim woman) became more popular. Islamic study sessions mushroomed in various cities. Mosque youth organizations grew in large cities and villages, organizing various events from Quran study to "Islamic fashion shows" and even "skate races." In universities, Masjids were the hotspots for student activities. These trends marked the rise of the religious Muslim middle class in the 1980s.

H. W. Dick noted that the emergence of the urban middle class was an important element in the history of the New Order. He asserted that even the New Order establishment itself was most accurately perceived as a "middle-class counter revolution," which reinitiated the rise of the middle class after its advance had been halted during the period of "guided democracy." ${ }^{61}$ The political stability brought about by the new regime, combined with the wealth from the oil boom in 1970, paved the way for the consolidation of the middle class, whose members were largely concentrated in metropolitan areas. ${ }^{62}$ The Islamic revival of the late $1970 \mathrm{~s}$ and $1980 \mathrm{~s}$ directly affected this urban middle class, which later spread the influence to other segments in the society.

One of the factors leading to this development was the vertical mobilization of religious Muslims. During the implementation of the Ethical Policy, the colonial government provided formal education for its colonial subjects, but limited it to the relatively less-religious aristocrats (i.e., priyayi). After independence, these Westerneducated aristocrats dominated the bureaucracy and the middle class. The mass education programs instituted by the Sukarno (anti-illiteracy programs) and Suharto (President Instruction-Based Elementary Schools, or SD Inpres) regimes provided these religious Muslims access to a formal education, giving them a ladder for vertical mobilization. The access to a formal education enabled Santri to climb into state bureaucracies, academic institutions, and the business sector, which were previously dominated by the secular, Western-educated aristocrats. ${ }^{63}$ Saefuddin himself had

\footnotetext{
${ }^{60}$ This curiousity led him to follow various talks by Saefuddin and to read his papers, and even led him to study Islamic economics for his master's degree. See Adiwarman's quote in Saefuddin, Membumikan Ekonomi Islam, p. 319.

${ }^{61}$ Howard W. Dick, "The Rise of a Middle Class and the Changing Concept of Equity in Indonesia: An Interpretation," Indonesia 39 (A pril 1985): 87-88.

${ }^{62}$ Ibid., pp. 71-90.

${ }^{63}$ Achmad Munjid, "Militant and Liberal Islam: The Unwanted Twin Children of ModernizationIndonesia, a Case Study," paper presented at AMSS (Association of Muslim Social Scientists in North America) 43rd Annual Conference, Temple University, September 30 to October 2, 2005.
} 
graduated from Justus Liebig University, in West Germany. ${ }^{64}$ When he arrived at Jakarta's airport, Mohammad Natsir, the former Masyumi leader, welcomed him. Many observers saw that the 1980s was the era marked by a "Muslim intellectual boom." As Kuntowijoyo asserted, in a statement recorded by Hefner, Muslims "joined the ranks of government and business and were ready to Islamize the large segments of the middle class and the ruling elite." ${ }^{65}$

Another factor in this rise of the Muslim middle class concerned the condition of the middle class itself. As Hefner noted, the new middle class was haunted by anxiety brought by rapid and confusing changes in urban areas. ${ }^{66}$ As a result, Indonesian Muslims, mainly youth in the big cities, were looking for a new understanding of religion that could provide them with a set of guidelines for private and family life and for dealing with the outside world. ${ }^{67}$ Moreover, the government policy was to force Islam out of politics by giving it room in society. Thus, Islamic activities, as long as they were non-political, were relatively free from government oppression.

The rise of a new Muslim middle class contributed to the development of an Islamic economy in Indonesia in many ways. First of all, most of the activists were coming from this middle class. Saefuddin was a German-educated intellectual. Amin Azis, the man who originally outlined the concept for the realization of Indonesia's first Islamic bank, graduated from Iowa State University, in the United States. Many supporters were students of state universities. Second, among members of the urban middle class, the demand for an Islamic way of doing things, including economic activities, was rising. In 1986, Nurcholish Madjid (or Cak Nur), a leading Muslim intellectual, established Paramadina, an urban proselytization center aimed at providing Islamic guidance for this cosmopolitan middle class. Many business executives and high-ranking government officials joined the classes held by Paramadina. In the competitive economy, where it appeared morals were losing influence, they were looking for moral guidance. The Islamic economy movement provided such guidance in financial affairs. Third, the rise of the religious Muslim middle class led to the emergence of $\mathrm{ICMI}^{68}$ which would prove pivotal in enabling the Islamic economy movement to gain governmental support in the late 1980s.

\section{From Foe to Friend: The State and the Islamic Economy}

In the early days of Indonesia's Islamic economy movement, the state did not support it. Some "warnings" were issued against its proponents, such as Saefuddin. The state was indeed suspicious that the movement was a new vehicle designed to help Muslim activists sneak into the political arena. However, the government did not see this movement as a serious threat, and thus allowed it to grow little by little,

\footnotetext{
${ }^{64} \mathrm{He}$ finished his PhD in Justus Liebig University in Giessen, West Germany.

${ }^{65}$ Robert W. Hefner, "Islam, State, and Civil Society: ICMI and the Struggle for the Indonesian Middle Class," Indonesia 56 (October 1993): 15.

${ }^{66}$ Ibid., pp. $13-16$.

${ }^{67}$ This observation originally came from William Liddle, quoted in Adam Schwarz, A Nation in Waiting, p. 174.

${ }^{68}$ For further elaboration on ICMI and Indonesia's middle class, see Robert W. Hefner, "Islam, State, and Civil Society," pp. 1-35.
} 
probably because the movement itself was cautious to distinguish itself from Political Islam. In the international arena, Suharto actively supported OIC (Organization of Islamic Conference) and IDB (Islamic Development Bank)-both these organizations had sponsored the birth of Islamic banks in various countries-as part of Indonesia's foreign policy. Indonesia also sent its Minister of Economy to various IDB occasions. Nevertheless, at this time, the government did not grant the Islamic economy project any room to maneuver within the national banking and financial system; they were not invited to institute Islamic banks. Furthermore, grassroots experimental institutions, such as Baitut Tamwil Teknosa, failed due to mismanagement. The support bases for the movement, mostly comprising students and Muslim activists, were situated far from that state bureaucracy. The future seemed bleak for the Islamic economy movement.

Events reached a tipping point following a political shift in the late 1980s (as I will discuss later), when MUI, the corporatist body that was designed to justify government policies, in part by issuing fatwas, was transformed into a platform for Muslim groups to influence government policies. As President Suharto tried to approach Muslim groups, the MUI was becoming more assertive. In this new environment, a fellow PPA figure, Amin Aziz, started to sketch out ideas for the establishment of Indonesia's first Islamic bank and organized lobbies for the realization of that vision.

At the same time, the increased activity of Muslim intellectuals made the MUI more inclined to listen to representatives of the growing middle class. In an MUIsponsored Cibogo meeting, May 1986, Forum Komunikasi Pembangunan Indonesia (FKPI, Communication Forum for the Development of Indonesia) was established. The main aim was to back up the MUI by providing recommendations from the perspective of Muslim intellectuals. ${ }^{69}$ PPA figures, including Amin Aziz, were actively involved in the forum. Furthermore, these Muslim intellectuals were accommodated by the MUI organization. Before this time, the MUI was mainly an organization of scholars trained in religious studies. In 1989, Amin Aziz became one of the secretaries of the MUI and the organization became more open to Muslim activists with no religious education background.

In FKPI discussions, the idea of establishing the first "real" Islamic financial institution was introduced. Using his position as a secretary of the MUI, Amin Aziz tried to enter the discussion by raising the issue of banking in Muslim society as an agenda item within the MUI National Summit, December 17-20, 1989. His effort was unsuccessful, simply because he was too late to propose the idea. ${ }^{71}$ Despite his failure to influence the agenda at the 1989 conference, the idea of an Islamic economic system successfully penetrated the MUI, which then played an important role by actively advocating the realization of the idea. On the March 12,1990, the secretary general of

${ }^{69}$ Zaim Uchrowi and Usman Ks, ICMI Bergerak: Lintasan 10 Tahun Ikatan Cendekiawan Muslim se-Indonesia, p. 40. Actually, many participants were willing to establish an organization of Muslim intellectuals. However, after discussing this proposal with figures from the MUI and the Ministry of Religion, they decided not to do so because they were worried about the government's response. Some participants-among the most vocal was Fuad Amsyari-kept pushing the idea to establish an organization. Finally, rather than an independent organization of Muslim intellectuals, FKPI was established as a forum to provide support for MUI.

${ }^{70}$ Ibid., p. 94. 
the MUI, H. S. Projokusumo, responded to the proposal. He expressed the eagerness of the MUI leadership to discuss the issue of banking in Muslim society. ${ }^{71}$ Before this point, different views among Indonesian Muslim groups on the status of interest were evident, but never seriously discussed within the MUI. ${ }^{72}$ On May 12, 1990, the MUI held a meeting to discuss the issue. Notable figures who attended the meeting were: K. H. Achmad Azhar Basyir (Muhammadiyah), H. Jarnawi Hadikusuma (Muhammadiyah), K. H. Ali Yafie (NU), Yunus Umar (NU), and Abdul Chalik Ali (the treasurer of $\mathrm{NU}$ ). Those attending the forum decided to hold a more intensive workshop on the status of interest and Islamic banking. To prepare the workshop, a committee was formed. Aziz was appointed to be the leader of the team, helped by another MUI figure, Syaifuddin A. Rasyid. ${ }^{73}$

After some months of preparation, an MUI workshop on banking and interest was held in the Safari Garden Hotel Cisarua, August 18-20, 1990, sponsored by the Hutomo Mandala Putra's Humpuss Group ${ }^{74}$ and several banks. ${ }^{75}$ Figures from the Central Bank of Indonesia were also invited to represent the government. The results of the workshop were then introduced at the Fourth National Summit of MUI in Sahid Jaya Hotel, Jakarta, August 22-25, 1990. At this summit, MUI finally recommended the establishment of a working group named Tim Perbankan MUI (MUI banking team) to create an Islamic bank in Indonesia. ${ }^{76}$

With this development, the MUI became the main platform for the Islamic economy movement, which sought to realize the vision of establishing an Islamic bank. After the establishment of the ICMI in December 1990, which most FKPI activists joined, that organization provided yet another platform for the Islamic economy movement. Many activists were involved in both the ICMI and MUI teams, including Amin Aziz. ${ }^{77}$

\footnotetext{
${ }^{71}$ Ibid., pp. 94-95.

${ }^{72}$ For further elaboration on different religious views concerning the status of interest, see Bachtiar Effendy, "Islamic Economic Institutions in Indonesia: A Religio-Political Perspective."

${ }^{73}$ Zaim Uchrowi and Usman Ks, ICMI Bergerak: Lintasan 10 Tahun Ikatan Cendekiawan Muslim se-Indonesia, pp. 95-96.

${ }^{74}$ Hutomo Mandala Putra, called Tommy Suharto, is Suharto's youngest son and the most controversial of Suharto's children. He founded his business enterprise, Humpuss Group, in 1984 at the age of twenty-two. Using his father's name assertively, Tommy maneuvered Humpuss to become a major player in various fields, including petrochemicals, wood manufacturing, fertilizer production, toll roads, sugar and palm-oil plantations, and advertising. Adam Schwarz, A Nation in Waiting, p. 143.

${ }^{75}$ Among the banks, the biggest donation came from Bank Exim (Export Import Bank), directed by Iwan Prawiranata, its CEO. Zaim Uchrowi and Usman Ks, ICMI Bergerak: Lintasan 10 Tahun Ikatan Cendekiawan Muslim se-Indonesia, pp. 95-96.

${ }^{76}$ Muhammad Syafii Antonio, Bank Syariah: Dari Teori Ke Praktek (Jakarta: Gema Insani Press, 2001). pp. 2526. It should be noted that the MUI recognized that there were different views on the status of "interest" (the three views: interest is riba [usury] and thus prohibited, interest is not riba and thus allowed, and that interest is mutasyabihat, in doubt, thus it is better to avoid but it is acceptable to pay interest in the case of an emergency). Indonesia's financial system did not have an institution that could serve those who believed that riba is prohibited. Thus, the MUI recommended the establishment of an Islamic bank. See also Hefner, "Islamizing Capitalism" (2003).

${ }^{77}$ Discussions on the evolution of the responses of Indonesia's Islamic scholars, including those in the MUI, towards the Islamic economy movement, can be found in Shofwan Al Banna Choiruzzad and Bhakti Eko Nugroho, "Securing Sustainable Support: Indonesia's Islamic Economy Project and the Islamic Scholars,"
} 
Through the MUI and the ICMI, the Islamic economy movement was able to reach Suharto. The ICMI particularly was a strong and influential vehicle, because it included Habibie, who at that time was the Minister for Science and Technology and acting as ICMI's chairman. According to many observers, Habibie was Suharto's most trusted aide since the late $1980 \mathrm{~s} .{ }^{78}$ The connection between Habibie and the president, the highest authority in New Order Indonesia, was successfully exploited by proponents favoring an Islamic bank and Islamic economy. The advocates believed that once Suharto declared his agreement, state institutions would follow. Amin Aziz himself talked at length with Habibie, who later proposed the idea personally to the president. ${ }^{79}$ The ICMI team also tried various other routes to reach Suharto, including attempts to influence him via Ginanjar Kartasasmita ${ }^{80}$ and lobbying the Minister of Religion, Munawir Sadzali, who was skeptical of the proposal. ${ }^{81}$

Brimming with confidence, Aziz convinced Habibie to establish teams to prepare seriously for the establishment the Islamic bank. Habibie asked Rachmat Saleh, ${ }^{82}$ former governor of Indonesia's Central Bank, to be the leader of the first team, which dealt with the institutional issues. Aziz was asked by Habibie to lead the second team, which was responsible for fund-raising programs. ${ }^{83}$

As a result of these connections, Suharto finally gave his blessing for the bank. Suharto's support paved the way for the establishment of Indonesia's first Islamic bank, Bank Muamalat Indonesia (BMI), on November 1, 1991. The process to choose the name of this new institution was also political. Before BMI was christened, various alternative names had been considered, including Bank Islam Indonesia, Bank Amal Islam Indonesia, Bank Muamalat Ummat Islam Indonesia, and Bank Muamalat Islam Indonesia. After some time, the committee proposed the name "Bank Muamalat Islam Indonesia." In response, Suharto erased the word "Islam" from the title, arguing that "Muamalat" itself is already Islamic. ${ }^{84}$ The Indonesian translation for "Islamic

paper presented in the Third International Conference on the Sustainable Future for Human Security (SUSTAIN) 2012, Kyoto University, November 3-5, 2012.

${ }^{78}$ Habibie was intentionally recommended to be the chairman of the organization by Imaduddin Abdulrahim, an influential figure among Muslim activists, who hoped, through this maneuver, to help establish a supportive environment for the new organization. Robert W. Hefner, "Islam, State, and Civil Society," pp. 16-22.

${ }^{79}$ Zaim Uchrowi \& Usman Ks, ICMI Bergerak: Lintasan 10 Tahun Ikatan Cendekiazan Muslim se-Indonesia, p. 98.

${ }^{80}$ Interview with Saefuddin, September 16, 2011. At the time, Ginanjar Kartasasmita was the Minister of Mining and Energy (1988-93). Later, he served as the head of the powerful National Development Planning Board (Badan Perencanaan Pembangunan Nasional, BAPPENAS), 1993-98. Ginanjar was known for his role in supporting the rise of pribumi businessmen since the 1970s through Tim 10 (Team 10), which was mandated to implement presidential decrees to give the "weak economic group" (i.e., indigenous / pribumi) priority in obtaining government contracts.

${ }^{81}$ The information was from the interview with Amin Aziz, August 31, 2000, conducted by Zaim Uchrowi and Usman Ks. See Zaim Uchrowi and Usman Ks, ICMI Bergerak: Lintasan 10 Tahun Ikatan Cendekiawan Muslim se-Indonesia, p. 98.

${ }^{82}$ Rachmat Saleh was the governor of the Central Bank of Indonesia (Bank Indonesia, BI) from 1973-83. He served as the Minister of Trade from 1983 to 1988.

${ }^{83}$ Zaim Uchrowi and Usman Ks, ICMI Bergerak: Lintasan 10 Tahun Ikatan Cendekiawan Muslim se-Indonesia, p. 97.

${ }^{84}$ Zaim Uchrowi and Usman Ks, ICMI Bergerak: Lintasan 10 Tahun Ikatan Cendekiawan Muslim se-Indonesia, pp. 98-99. 
banking" was also influenced by this political factor. Instead of "perbankan Islam" (the literal translation of Islamic banking), "Islamic banking" was translated as "Perbankan Syari'ah" (literally, "Shari'a Banking"). ${ }^{85}$

Suharto himself led the fund-raising event for the Islamic bank. On Sunday, November 3, 1991, the MUI held an event entitled "Silaturahmi Bapak Suharto dan Masyarakat Jawa Barat dalam Rangka Pendirian Bank Syariah" (Meeting between Bapak Suharto and West Java Citizens for the Establishment of the Islamic Bank). The event was attended by important figures from the government and the business sector, including Sudharmono (Vice President), Emil Salim, Ali Alatas, J. B. Sumarlin, Ginanjar Kartasasmita, Ponco Sutowo, Probosutejo, and many others. ${ }^{86}$ Another fundraising event had been held earlier, at the Sahid Jaya Hotel and led by businessman Sukamdani S. Gitosarjono, who was appointed one of the commissioners of BMI. ${ }^{87}$ From the two events, the committee successfully raised the total funds for the establishment of the BMI to more than 106 billion IDR. ${ }^{88}$

Additional significant help came from the Central Bank (BI), following Suharto's blessing, which formed a special team to assist the establishment of the Islamic bank and even asked several related actors to participate. The team was led by Subarjo Joyosumarto and included Siti Fajriyah, Ramzi A. Zuhdi, and Muchtar Syafi'i. Due to the limited reach of the Islamic economy movement in the 1980s, most of these officials knew nothing about Islamic banking and had to start from scratch. Some of their colleagues in the Central Bank often joked to them that "BMI" is the acronym for "Bank Mustahil Indonesia" (Indonesia's Impossible Bank), but they continued the project. ${ }^{89}$ Bank Indonesia also asked Robby Johan, the director of Bank Niaga, to lend his support. Responding to the request, Johan sent Aries Muftie. Later, Muftie was appointed as BMI's first head of operations.

However, there were several problems remaining to be solved. First, the funds to initiate the bank were all still "pledges"; it took time to collect the money that had been

\footnotetext{
${ }^{85}$ Sugiharto (former minister of State-Owned Corporations/BUMN [Badan Usaha Milik Negara], former United Development Party [Partai Persatuan Pembangunan, PPP] politician, ICMI Chairman for Economic Empowerment) and Muliaman Hadad (deputy governor of Bank Indonesia and chairman of the Indonesian Society for an Islamic Economy) mentioned this in their speeches reflecting on the growth of the Islamic economy in Indonesia during the MES's Iftar Event (Buka Puasa Bersama MES), August 15, 2011. I heard similar information regarding these developments in an interview with Harisman, the former head of the Central Bank Bureau for the Islamic Banking Sector (Kepala Biro Perbankan Syariah Bank Indonesia), August 15, 2011; an interview with Aries Muftie, September 12, 2011; an interview with Irfan Syaugi Beik, Director of Islamic Economics Program, Bogor Institute of Agriculture and one of the chairmen of IAEI (Indonesian Islamic Economics Scholars Association), September 9, 2011; and an interview with Saefuddin, September 16, 2011.

${ }^{86}$ Uchrowi and Ks, ICMI Bergerak, pp. 91-93.

"I Ibid., pp. 92-93; and Hefner, "Islamizing Capitalism" (2003), p. 156. Those two sources mention different dates for the fund-raising event at the Hotel Sahid. Hefner reported that the event was held on October 13, 1991, while Uchrowi and Ks write that it was held two days before the event in Bogor, or on November 1, 1991. Since November 1, 1991, is also the date on which BMI was formally established, I suspect that Uchrowi and Ks may have mixed up the two different events. Another possibility is that while the actual fund-raising was held on October 13,1991, the commitment was formally signed-together with the signing event for the establishment of BMI—on November 1, 1991.

${ }^{88}$ Muhammad Syafii Antonio, Bank Syariah: Dari Teori Ke Praktek, pp. 25-26.

89 "Subarjo Joyosumarto: Pelopor Bank Mustahil di Indonesia," Jurnal Nasional Daily, October 11, 2011.

${ }^{90}$ Interview with Aries Muftie, September 12, 2011.
} 
promised. According to Aries Muftie, he was responsible for collecting these promised funds, and that effort continued even after the BMI was fully operating. The second problem seemed more troublesome: the existing regulations on banking did not cover any banks operating without interest, even though they did present a possibility for the operation of a bank that charged a zero percent interest rate. Coincidentally, and fortunately for the project, the government was in the process of amending the existing regulations on banking (i.e., the 1967 Banking Law, the October Policy Package of 1988 [Paket Kebijakan Oktober 1988, or Pakto 88], and the January 1990 Package [Paket Kebijakan Januari 1990]). ${ }^{91}$ Given Suharto's support for the BMI, the Islamic economy movement advocates were confident enough to lobby government officials charged with amending the regulations to include a clear legal basis for the operation of a bank that operates without interest.

After some lengthy lobbying, on March 25, 1992, Law No. 7/1992 on banking was issued. The new law briefly mentioned that it was permissible for a bank to provide services based on the principles of profit-sharing, in article 6 point $(\mathrm{m})$, thus providing a strong legal basis for the operation of the BMI. ${ }^{92}$ Two months later, in May 1992, the BMI started to operate. The first managing director (direktur utama) was Zainulbahar Noor. Following the enactment of the new law on banking, October 30, 1992, the government issued Government Regulation No. 72/1992 on a Profit-sharing Based Bank (Peraturan Pemerintah No. 72/1992 tentang Bank dengan Berdasarkan Prinsip Bagi Hasil). The BI then issued operational guidelines for Profit-sharing-based Banks with the BI Governor's Letter No. 25/4/BPPP on February 29, 1993. To learn more about the practices of Islamic banking and finance, BI sent its officials abroad to study other banks in operation that relied on profit-sharing, not interest fees. ${ }^{93}$

In 1994, BMI opened branches in Bandung, Surabaya, and Semarang. ${ }^{94}$ These new institutions were warmly welcomed by state officials. The Bandung branch grand opening was marked with a bedug ceremony led by the vice governor of West Java Province, H. A. M Sampurna. ${ }^{95}$ The Surabaya branch was opened by the governor of East Java Province, Basofi Sudirman, who was also the first customer at the bank. ${ }^{96}$

The growth of BMI and the warm responses from the government made the activists more confident and ready to try additional projects. Many other initiatives were launched in this period, including the introduction of baitul maal wat tamwil (BMT). Often Indonesianized as Balai Usaha Mandiri Terpadu, or One-stop Independent Enterprises Center, BMT is an institution that combines the functions of non-profit social institutions (i.e., managing religious funds such as zakat and infag) and profitoriented intermediary institutions. The BMT was designed to be an alternative source of funding for small- and micro-size grassroots enterprises, which lacked access to

\footnotetext{
${ }^{91}$ Interview with Ali Sakti, senior researcher at Central Bank of Indonesia, August 11, 2011.

${ }^{92}$ See Undang Undang No. 7 tahun 1992 tentang Perbankan (Law No. 7/1992 on banking).

${ }^{93}$ Interview with Harisman, former head of the Central Bank's Bureau for the Islamic Banking Sector (Kepala Biro Perbankan Syariah Bank Indonesia), August 15, 2011. Also from "Subarjo Joyosumarto," Jurnal Nasional Daily.

94 “BMI Membuka Cabang di Kota Bandung," Republika Daily, July 19, 1994; and "BMI Berikan Layanan Bagi Hasil Sesuai Syariat Islam,"Republika Daily, November 18, 1994.

95 "BMI Membuka Cabang di Kota Bandung," Republika Daily.

96 “BMI Berikan Layanan Bagi Hasil Sesuai Syariat Islam," Republika Daily.
} 
banks. Unlike the Islamic bank, which had been accommodated by the Law on Banking, the BMTs' legal status was unclear at their inception. Because of this situation, BMTs were operated as "cooperatives," even though they were conceptually different. ${ }^{97}$ ICMI played an important role in the development of BMTs. In 1994, Dompet Dhuafa (literally "The Poor's Pocket"), a zakat management institution with an affiliation to Republika Daily, an ICMI-affiliated newspaper, launched the program to establish "1001 BMTs and Islamic Rural Banks" in Indonesia. ${ }^{98}$ In the mid-1990s, ICMI sponsored the establishment of BMTs in various provinces. ${ }^{99}$

Also during this period, in the 1990s, many previously informal discussions on Islamic economics became more organized and structured, most notably in universities, where the discussions expanded and, in time, became part of the curriculum. At the University of Indonesia, for example, a student group named "Iqtishodi" was developed with the specific aim to discuss and spread the ideas related to Islamic economics. Since the establishment of the BMI and the growth of other institutions such as BMTs and Islamic rural banks, there were more real examples of Islamic economic-based institutions available to study. Many Islamic economy activists who were engaged in business supported these student groups. In the UI, Adiwarman Karim from the BMI was among the "teachers" in the Iqtishodi study group. ${ }^{100}$ These groups were the embryo for the spread of the Islamic economy movement in academia. Alumni from UI's Iqtishodi, for example, are now actively involved in the university's Pusat Ekonomi dan Bisnis Syariah (PEBS, Center for Islamic Economy and Business) and Ikatan Ahli Ekonomi Islam (IAEI, Indonesian Islamic Economics Scholars Association). Some of these students then became lecturers and were pivotal in the inception of Islamic economics in formal academic institutions.

While it did not adopt Islamic economic concepts as a guide for the whole economic system or the national economic strategy, the government at least did not interfere with the growth of the Islamic economy movement. In various events, government officials praised the "Islamic economy" as a positive contribution for development. ${ }^{101}$ Harmoko, the Minister of Information, praised the MUI's efforts to

${ }^{97}$ Interview with Aries Muftie, September 12, 2011. See also Minako Sakai, "Community Development through Islamic Microfinance: Serving the Financial Needs of the Poor in a Viable Way," pp. 267-85.

${ }^{98}$ Eri Sudewo, "Dari Dompet Dhuafa Republika: Forum Ekonomi Syariah," Republika Daily, November 10 , 1994.

${ }^{99}$ For example, see "Di Aceh dan Lampung akan Beroperasi 85 Baitul Maal wat Tamwil," Republika Daily, September 20, 1994.

${ }^{100}$ Author's interviews with Syamsoe Badaruddin and Yan Orgianus, August 8, 2011; and with Yusuf Wibisono and Banu Muhammad, August 12, 2011.

${ }^{101}$ During the New Order, economic technocrats were important actors in the state's bureaucracy. Many of them were skeptical regarding Islamic banking, as demonstrated by their support for Abdurrahman Wahid's initiative to establish the NU-Summa bank. However, the political climate (i.e., Suharto's support, Habibie's growing influence, and the portrayal of these technocrats as anti-Islam culprits in Muslim circles) made them hesitate to critique openly the idea of an Islamic bank. For evidence of this skepticism, see Timur Kuran, Islam and Mammon: The Economic Predicaments of Islamism (Princeton, NJ, and Oxford: Princeton University Press, 2004). While Kuran was not writing about Indonesia, many Indonesian economists, who did not speak out publicly, questioned Islamic economics and Islamic banking in the same way Kuran did (for example: "Islamic banks are conventional banks in Islamic dress," "profit in Islamic bank is interest with a different label"). It must be noted, though, that some economists also responded positively to the concept. In 2011, Bambang Sumantri Brojonegore, the former dean of the Faculty of Economics of the University of Indonesia, traditionally the bastion of the technocrats, was 
develop religious alms institutions within various regions and connect them to the poor using the chief Islamic bank, BMI, and the Islamic rural bank. He said that government supported the MUI's efforts to help eradicate poverty by developing an Islamic economy that would directly benefit the poor. ${ }^{102}$ The Minister of Health, Sujudi, and the Minister of Trade, Satrio Budiharjo, were also present at ICMI's event to launch the BMTs in Aceh and Lampung. ${ }^{103}$ In addition, the government granted powerful authority to the MUI by obliging all profit-sharing-based banks to be overseen by Dewan Pengawas Syariah (DPS, Shari'a Compliance Monitoring Board). ${ }^{104}$

The not-so-negative response by the Suharto regime to the development of Islamic banking created incentives for both idealistic activists of the Islamic economy movement and more pragmatic business players to establish related services in other financial sectors. In 1994, the first Islamic Insurance service in Indonesia, PT Asuransi Takaful Keluarga, was established. ${ }^{105}$ Around the same period, non-governmental institutions focusing on the management of zakat were starting to grow, as noted above. Before this time, zakat and other religious alms were managed by religious figures or local mosques and the local government body. Many activists saw that those existing institutions were not managed professionally and thus did little to empower the poor. The pioneer institution of this kind was Dompet Dhuafa, founded by figures related to the newspaper, Republika, such as Parni Hadi and Eri Sudewo. With the vision of empowering the poor and the marginalized ummah, these zakat institutions effectively joined the Islamic economy movement. ${ }^{106}$ Many Islamic economists came to study zakat as a developmental strategy and viewed it as an integral part of the Islamic economy project. The issuance of law on zakat was also put forward as the agenda of the Islamic economy movement. ${ }^{107}$ Zakat management institutions established Forum Zakat (FOZ, Zakat Forum) on September 19, 1997, as a communications forum and to advocate for its interests through legislation.

The need for experts on Islamic economics grew apace. In the 1990s, many Indonesians traveled abroad to study in countries established as centers for the field, such as the United Kingdom, Pakistan, and Malaysia. Domestically, several academic institutions introduced Islamic economics as an academic subject. These developments in the academic field helped Indonesia's Islamic economy movement connect with the global Islamic economy. According to Irfan Syauqi Beik, Indonesian Islamic

appointed as the chairman of Ikatan Ahli Ekonomi Islam (IAEI). This year, 2013, the Faculty of Economics of the University of Indonesia has opened a "Department of Islamic Economics." Therefore, a further investigation on the dynamics of the responses of Indonesia's economic technocrats towards the Islamic economy movement is needed.

102 "Komisi Pengentasan Kemiskinan," Republika Daily, May 2, 1994.

103 "Di Aceh dan Lampung akan Beroperasi 85 Baitul Maal wat Tamwil," Republika Daily.

${ }^{104}$ Members of the DPS were elected by each bank, but only after consultation with MUI. See Government Regulation No. 72/ 1992 on Profit-sharing Based Banks (Peraturan Pemerintah No. 72/1992 tentang Bank dengan Berdasarkan Prinsip Bagi Hasil).

105 PEBS FEUI, Indonesia Shariah Economic Outlook 2011, p. 31.

${ }^{106}$ Interview with Nana Mintarti, the Director of Indonesia Magnificence of Zakat, a think tank on zakat affiliated with Dompet Dhuafa, October 14, 2010.

${ }^{107}$ Interview with Irfan Syauqi Beik, September 9, 2011. 
economists started to be exposed to their global counterparts in the 1990s, after a period of self-development in the 1980 s and early 1990 s. ${ }^{108}$

\section{Behind the Establishment of Bank Muamalat Indonesia}

In the New Order, state decision making was centralized in the hands of Suharto, the highest authority. Given this context, one can safely assume that the state gave the green light for the foundation of Indonesia's Islamic bank because Suharto himself decided to tolerate it.

Suharto's decision to accommodate the Islamic bank and even to assist personally in the fund raising significantly changed the attitudes of other state officials. As noted above, even the Minister of Religion, Munawir Sadzali, was not really supportive of the idea of Islamic banking. ${ }^{109}$ Nevertheless, Sadzali changed his stance after he recognized Suharto had given the project a green light. All state bureaucracies followed suit, in time, from the minister of finance to the administrators of the Central Bank. Suharto's blessing was a key factor in determining that an article on Islamic banking would be included in the new Law on Banking, Law No. 7/1992. ${ }^{111}$

Other motivations did affect the state bureaucracies and their attitudes toward these innovations. For example, Subarjo Joyosumarto, from the Central Bank, was supportive of Islamic banking because he saw that many Muslim communities in some Muslim majority regions, such as the northern part of Java, Madura, and West Sumatra were not using banking services except in emergencies. When Muslims in these regions used the banking services, many of them still rejected the interest and thus created accounting problems for the banks. ${ }^{111}$ Thus, despite skepticism from fellow BI officials, Subarjo saw that the establishment of an Islamic bank would help the development of the national banking system by integrating these communities into the system. These supportive BI officials did realize that, without Suharto's positive response to the idea of an Islamic bank, the BI certainly would not take further action. ${ }^{112}$

What were the factors that motivated Suharto to accommodate the Islamic economy movement in the 1990s?

\footnotetext{
108 Ibid.

${ }^{109}$ He was of the view that "interest" does not qualify as riba. Of course, he is not alone in holding this view. However, he was skeptical about the idea of Islamic banking, and, as noted, he applauded Abdurrahman Wahid, who established a joint venture bank between NU and Summa, operating based on interest. See Zaim Uchrowi and Usman Ks, ICMI Bergerak: Lintasan 10 Tahun Ikatan Cendekiawan Muslim seIndonesia, p. 101.

${ }^{110}$ Interview with Saefuddin, September 16, 2011.

${ }^{111}$ Zaim Uchrowi and Usman Ks, ICMI Bergerak: Lintasan 10 Tahun Ikatan Cendekiawan Muslim se-Indonesia, pp. 100-101.

${ }^{112}$ Interview with Harisman, former head of the Central Bank Bureau for the Islamic Banking Sector (Kepala Biro Perbankan Syariah Bank Indonesia), August 15, 2011. Also from the interview with Nusirwan and Ali Sakti, senior researchers at Central Bank of Indonesia, August 11, 2011.
} 


\section{Suharto's Changing Approach to Muslim Groups}

Suharto's support for the foundation of Indonesia's first Islamic bank was not the first or only positive gesture directed towards Islamic groups by the president in the late 1980s and 1990s. After having long been perceived as a modern day Pharaoh among Muslim groups for his oppressive policies against Political Islam and even the symbols of Islam in the society, Suharto changed his approach. While keeping the strictest curbs on Political Islam, the government eased restrictions on the use of jilbab by Muslim women in public schools (1991), facilitated the establishment of religious facilities across the archipelago under the Yayasan Amal Bakti Muslim Pancasila, reformed the national education law and religious judiciary law (1988), accommodated the requests by Muslim groups to ban SDSB (Sumbangan Dana Sosial Berhadiah, a kind of lottery for providing development funds), scheduled Arabic language lessons on state television, sponsored the Istiqlal Festival, and supported the establishment of the ICMI. ${ }^{113}$ Personally, Suharto also demonstrated more religious behaviors-he went to Mecca for the pilgrimage in 1990 and added "Muhammad" to his name.

There are different explanations for this development. ${ }^{114}$ On one side, many have suggested that Suharto's changing attitude towards Islam was a political strategy. In the late 1980s, the president found that members of the military's top brass were unhappy with the growing influence of Suharto's sons and daughters in the business sector. L. B. Murdani criticized the development, provoking Suharto's suspicion of Murdani's loyalty. ${ }^{115}$ Having lost an important political ally in the military, Suharto shifted closer to Muslim groups, according to this theory, in order to embrace a new ally to strengthen his regime.

Another explanation for Suharto's shift in attitude theorizes that he started to recognize a broader change in Indonesian society-the deepening of Islamization in the urban middle class. According to this explanation, Suharto's break up with his former ally in the military, who staunchly oppressed Muslim groups in the 1980s, was the result of this recognition, and not the other way around.

Whatever the correct explanation is, Suharto did change his attitude towards Islamic and Muslim groups in the late 1980s. His response toward the Islamic economy movement, including the establishment of Indonesia's first Islamic bank and many Islamic rural banks thereafter, was part of this trend. Furthermore, Suharto's family saw the importance of supporting Muslim endeavors. Tommy Suharto was among the first financiers of the first MUI Workshop on Islamic banking in 1990.

\footnotetext{
${ }^{113}$ Zaim Uchrowi and Usman Ks, ICMI Bergerak: Lintasan 10 Tahun Ikatan Cendekiawan Muslim se-Indonesia, pp. 26-27.

${ }^{114}$ For further discussions, see Robert W. Hefner, "Islam, State, and Civil Society," pp. 1-35; Adam Schwarz, A Nation in Waiting, pp. 162-93; Zaim Uchrowi and Usman Ks, ICMI Bergerak: Lintasan 10 Tahun Ikatan Cendekiawan Muslim se-Indonesia, pp. 17-31. The two different perspectives on the factors behind Suharto's changing attitude were mainly summarized from these sources.

${ }^{115}$ For the dynamics on the relationship between Suharto and military leaders in the 1980s, see Jun Honna, Military Politics and Democratization in Indonesia (London and New York, NY: Routledge Curzon, 2003).
} 


\section{The Habibie Factor and the Conflation of Economic Discourses in ICMI}

Another important factor behind Suharto's blessing was Habibie, Suharto's mosttrusted political ally in the 1990s. However, while Habibie's role in accelerating the development of an Islamic economy should not be underestimated, it is important to note that Habibie had his own vision for the economy and development. His support for the Islamic economy project could be explained by two factors: 1) The patronage relationship between Habibie and ICMI, formalized by his position as the chairman of the association; and 2) the conflation of economic perspectives within the ICMI, which had mixed up-at least in its rhetoric-Islamic economics, people/populist economics, and Habibienomics.

To understand these two factors, one needs to understand Habibie's economic view ("Habibienomics") and his battle for influence in the Indonesian state bureaucracy following his return to the country in 1974.

Known for his achievements in the field of aeronautical engineering in Germany, Habibie was invited to return to Indonesia by President Suharto in 1974 in order to help develop high-tech industries. Habibie almost immediately challenged the dominance of Indonesia's economic technocrats. As noted by Takashi Shiraishi, Habibie could not count upon the support of such international financial agencies as the IMF and the World Bank, institutions that Indonesia's technocrats, his competitors, were able to tap to their advantage. However, Habibie had secured Suharto's personal patronage and had direct access to the president. ${ }^{116}$ High-technology industry was at the core of his economic vision, which he tried to realize through government policies. His economic vision collided with the economic strategy outlined by the economic technocrats who previously dominated policy making on development. "Habibienomics" collided with "Wijoyonomics," named after Wijoyo Nitisastro, the most prominent and senior figure in the group of economists who advocated development policies based on the principles of neoclassical economics. ${ }^{117}$

Both Habibienomics and Wijoyonomics agreed on the importance of economic growth and industrialization. However, as Sulfikar Amir has noted, they disagreed in their views of the sources of economic development and the foundation of industrialization. The economists believed that comparative advantage is the key if a nation seeks to prevail in a globalized economy. Thus, they recognized Indonesia's abundant natural resources and cheap labor as the most important sources of economic development. Habibie and his group of engineering technocrats believed that this view was obsolete. They argued that this strategy was appropriate for the early period of development, but no longer sustainable because Indonesia's natural resources were not unlimited and labor's wages were bound to rise as the economy grew. According to Habibie and his supporters, Indonesia should take a new direction for development. The key for this new direction would be to enhance and benefit from the added value of industrial products. The implication for this different strategy was enormous for the

\footnotetext{
116 Takashi Shiraishi, "Rewiring the Indonesian State," in Making Indonesia: Essays on Modern Indonesia in Honor of George McT. Kahin, ed. Daniel S. Lev and Ruth McVey (Ithaca, NY: Cornell Southeast Asia Program Publicaitons, 1996), p. 175.

117 Sulfikar Amir, "The Engineers versus the Economists: The Disunity of Technocracy in Indonesian Development," Bulletin of Science, Technology, and Society 28, 4 (August 2008): 316-23.
} 
state's policy. Habibie called for the government to take an active role in supporting technological endeavors, including providing protection and subsidies. This proposal was heavily criticized by the economists, who argued that it would disrupt the stability of Indonesia's economic structures and distort market mechanisms. ${ }^{118}$

In 1976, Habibie and his group successfully established the Indonesian Aircraft Industry (Industri Pesawat Terbang Nusantara, IPTN) in Bandung. Slowly but surely, boosted by Suharto's growing passion for high technology, Habibie gained more and more influence in the government bureaucracy. During the 1980s, the influence of the economists and Habibie supporters in the bureaucracy seemed about equal. The economists controlled the National Development Planning Board (BAPPENAS) and the key positions in the ministries of finance, trade, and industry, while Habibie supporters established strongholds in the Agency for the Assessment and Application of Technology (Badan Pengkajian dan Penerapan Teknologi, BPPT) and the Agency for Strategic Industries (Badan Pengembangan Industri Strategis, BPIS). From the early 1990s, Habibie and his supporters seemed to gain advantage, relative to the economists, by being directly involved in politics. ${ }^{119}$ The ICMI and the Islamic economy entered the story at this period.

When the ICMI's leadership position was offered to Habibie, he probably saw this as an opportunity to gain more political support for his development agenda and to win his battle against the economists. At the same time, Muslim activists who planned to establish the ICMI saw Habibie as an ideal candidate: a world-renowned intellectual, a devout Muslim, and a person close to Suharto. ${ }^{120}$ When Habibie agreed to lead the ICMI and brought his supporters into the association, his economic vision started to be conflated with other discourses from various elements within the ICMI.

Since the founding of ICMI, and even up until today, Indonesia's "nationalist economics" (representing Habibie's industrial nationalism, which favors high-tech industrial development and employs nationalist rhetoric ${ }^{121}$ ), "people/populist economics" (ekonomi kerakyatan, advocated by civil society activists such as Adi Sasono), and "Islamic economics" (ekonomi Islam, supported by A. M. Saefuddin and Amin Aziz) were the three key phrases in the ICMI's economic discourse. While the three concepts came from different branches of economic thinking, and thus contracted one another in certain aspects, the ICMI activists often presented the three as integrated, even synonymous, or at least as complementary. ${ }^{122}$

\footnotetext{
${ }^{118}$ Ibid., pp. 319-21. Takashi Shiraishi has argued that Suharto supported Habibie not simply because he liked him, but because Suharto had a strategic vision that involved creating shortcuts to industrialization. Another reason concerned internal security, because Suharto wanted Indonesia to become less dependent on foreign sources for military procurement. For further discussion of Habibie's ascendancy and the motivation behind Suharto's support, see Takashi Shiraishi, "Rewiring the Indonesian State," pp. 164-79.

${ }^{119}$ Amir, "The Engineers versus the Economists," pp. 318-19.

${ }^{120}$ Robert W. Hefner, "Islam, State, and Civil Society," p. 17. See also Zaim Uchrowi and Usman Ks, ICMI Bergerak: Lintasan 10 Tahun Ikatan Cendekiawan Muslim se-Indonesia, pp. 3-4.

${ }^{121}$ On how Habibienomics employs nationalist rhetoric, see Sulfikar Amir, "Nationalist Rhetoric and Technological Development: The Indonesian Aircraft Industry in the New Order Regime," Technology in Society 27,3 (2007): 283-89.

${ }^{122}$ Zaim Uchrowi and Usman Ks, ICMI Bergerak: Lintasan 10 Tahun Ikatan Cendekiawan Muslim se-Indonesia, pp. 91-113. For a sample of ICMI's present discourse on the economy, see also "Results of 5th ICMI
} 
Apart from the organizational reason to maintain unity, all three perspectives were united by one shared characteristic: they challenged the interpretations of the economic technocrats. Habibie resented the economists and competed with them in the state bureaucracy, while the supporters of the "people economy" and the "Islamic economy" resented them due to the results of their governmental policies, which were perceived as favoring a few powerful business persons (most of whom were not Muslims) while neglecting the poor and the majority of Indonesia's citizens (who were mostly Muslims).

Given this background, we can conclude that the Islamic economy movement benefited from Habibie's leadership in the ICMI. Habibie accepted the invitation to chair the organization in order to secure necessary support to realize his vision regarding development. The Islamic economy movement was using ICMI as one important platform to realize its own vision of the economic system. The discourses concerned with an Islamic economy, a people/populist economy, and Habibienomics then came together in ICMI's discourse. The conflation of the discourses secured Habibie's support for the Islamic economy movement because it was seen as part of the ICMI agenda. The establishment of Indonesia's first Islamic bank and other related projects were incorporated in ICMI projects.

\section{"Pribumi" Businessmen and the Rhetoric of Anti-Chinese Domination}

Another important factor that strengthened the Islamic economy movement in the 1990s was the role of pribumi (indigenous, a contrast to Chinese-Indonesian) businessmen. When Suharto initiated a fundraising event for the establishment of the the BMI, most of the funding came from this group of entrepreneurs. Ginanjar Kartasasmita, Aburizal Bakrie, Fahmi Idris, Fadel Muhammad, Sukamdani S. Gitosarjono, and other pribumi businessmen would also come forward to support the endeavor. ${ }^{123}$

Since the BMI was the first Islamic bank in Indonesia, there was no clear precedent for operating an Islamic bank or testing whether it would profit those who invested in it. Therefore, it can be assumed that the main motivation of those willing to channel their funds into the establishment of the bank was not for profit. Apart from the urgency to respond to Suharto's call to support the endeavor, a deeper motivation was present.

After the oil bonanza in the 1970s, economic nationalists within the regime started to argue for affirmative action to redistribute the wealth. Several presidential decrees gave the "weak economic group" (i.e., indigenous/pribumi) priority in obtaining government contracts, as noted above. The policy was implemented by Team 10, led by Sudharmono and Ginanjar Kartasasmita. From this affirmative strategy, new pribumi businesses sprang up. Because of the pivotal role of Ginanjar Kartasasmita, pribumi businessmen who profited from and ascended to power through this strategy, such as Aburizal Bakrie (of Bakrie Group), Fadel Muhammad (of Bukaka Teknik

National Conference" (No. 08/Tap/M-V/ICMI/2010); and ICMI, 20 Tahun ICMI: Melanjutkan Long March di Milenium ke-21 (Jakarta: ICMI, 2010).

${ }^{123}$ Uchrowi and Ks, ICMI Bergerak, pp. 91-93. 
Utama), and Imam Taufik (of Gunanusa Utama Fabricators), were known as "Ginanjar Boys." 124

When Habibie arrived in 1974 and started to wage his struggle against the domination of the economists in the bureaucracy, Ginanjar was among his sympathizers. Although their economic views were not identical, as Habibie did not care who got the contract for the high-tech industrial projects, and some pribumi businessmen who were groomed by Ginanjar complained because Habibie forced them to provide money for his ambitious projects, both were critical of the economists. ${ }^{125}$ According to Ginanjar's nationalistic view, the economists' development strategies were unfairly benefiting the Chinese-Indonesians because they had more capital to work with, compared to the pribumi groups. The resentment against ChineseIndonesian entrepreneurs grew because many Indonesians thought they had been favored by the government through deals often marred by corruption. In 1972, 80 percent of the state bank credit had gone to Chinese capitalists. ${ }^{126}$

Having gained power as the result of affirmative strategies to redistribute the wealth, strategies meant to challenge the domination of Chinese-Indonesians, this group of pribumi businessmen naturally reacted negatively to Chinese-Indonesian conglomerates. On many occasions, they protested against Chinese domination to gain both government support (and government contracts) and popular support for their agendas. Similar resentment surfaced among the supporters of the Islamic economy movement, and even among members of the ICMI, at least during the 1980s to the 1990s, for many of them viewed the domination of Chinese-Indonesians as proof that the economic system was unjust. Seeing the ICMI as an important political ally that could influence government development policy, these businessmen supported the ICMI and its programs, including the establishment of Indonesia's first Islamic bank.

Ever since the fall of the New Order, these pribumi businessmen have continued to employ rhetoric accusing the Chinese of dominating Indonesia's economy. Furthermore, this rhetoric still resonates with those in the Islamic economy movement. In his Republika article published in 2000, Agus Wahid, a staff member at BMI, quoted Aburizal Bakrie's claim that Chinese Indonesians controlled at least 60 percent of Indonesia's economy; Wahid advocated an Islamic economy as the best method to end this domination and strengthen Muslims' economic power ${ }^{127}$ Given this history, the appearance of a Chinese businessman in the 2008 Islamic bank commercial and the inclusion of Hermawan Kartajaya, a Chinese-Catholic Indonesian, in the BI Islamic Banking Committee (Komite Perbankan Syariah, KPS), were interesting developments.

\footnotetext{
${ }^{124}$ Adam Schwarz, A Nation in Waiting: Indonesia's Search for Stability, pp. 115-20.

${ }^{125}$ For an example, see "Wawancara dengan Arifin Panigoro: Buat Saya IPTN Saja Tidak Masuk Akal, Apalagi DSTP" ("For Me, even IPTN Was not Making Sense, DSTP [Dua Satu Tiga Puluh, 2130, a jet project] is Worse"), http:/ / www.tempo.co.id/ang/min/03/23/ekbis4.htm, accessed March 16, 2013

${ }^{126}$ Richard Robison, Indonesia: The Rise of Capital (NSW: Allen \& Unwin, 1988), pp. 325-27.

${ }^{127}$ Agus Wahid, "Memperkuat Posisi Ekonomi Ummat" (Strengthening the Ummah's Economic Position), Republika Daily, November 17, 2000.
} 


\section{Short but Pivotal: Habibie's Presidency (1998-99)}

The establishment of the BMI in 1991 obviously strengthened the momentum of the Islamic economy movement. However, the aforementioned factors surrounding the state's decision to allow the project to go forward have shown that the nature of the support was largely "accommodative," rather than seriously committed.

For many Islamic economy activists at this time, the Islamic economy project seemed stalled. There was no clear regulation that would allow further development of an Islamic economy. The state allowed, and even supported, the growth of the BMI, but there were still many limitations that impeded the growth of Islamic banking and finance. Law No. 7/1992 did mention that banks and other financial institutions would be permitted to operate based on the principles of profit-sharing, but did not explicitly mention "Islamic banking" (bank syariah). The BI also prohibited a "dual banking system." Thus, interest-based banks could not open services that were based on the profit-sharing principle. To open a profit-sharing-based bank, one had to start from scratch. Thus, due to the lack of capital, the development of the Islamic economy movement took place mostly at the grassroots level, through the proliferation of BMTs, Islamic rural banks (Bank Perkreditan Rakyat Syariah, microfinance), and zakat institutions.

In 1997, Indonesia was badly hit by the Asian financial crisis. As the economy collapsed, all discontent against the New Order exploded and sparked political unrest, calling for political reform. Faced by dwindling military and civilian support, Suharto resigned on May 20, 1998. Habibie, vice president at the time, a close aide to Suharto and a patron for the ICMI (and also the Islamic economy movement), was placed in an uneasy situation, but finally seized the opportunity to become the president during the transition. Although it lasted just a short time, the Habibie presidency, 1998-99, was pivotal for the Islamic economy movement.

Habibie's rise to the presidency disrupted ICMI's economic agenda, to an extent. As part of the economic and financial restructuring measures imposed under the International Monetary Fund auspices, Habibie's economic development projects-one key element in ICMI's economic discourse-were put to an end. BPIS was disbanded in August 1998. ${ }^{128}$ Ironically, the other elements of the ICMI economic discourse, namely the "people's economy" and the "Islamic economy," which had not been directly advocated by Habibie, successfully used the momentum supplied by his presidency. Adi Sasono, the core figure of the "people economy" discourse in the ICMI, was appointed as the Minister of Cooperatives and Small and Medium Enterprises. Saefuddin, the leading figure of Indonesia's Islamic economy movement, was asked to be the Minister for Food and Horticulture. The conflation of the "Islamic economy" and the "people's economy" discourses served to link their development during this period. The projects proposed by the Islamic economy proponents were often offered as part of the agenda by the advocates for a people's economy. One example for this interrelationship was the establishment of Permodalan Nasional

${ }^{128}$ Irawan Saptono/ Silvester Keda, "Membubarkan Warisan Habibie," Tempo Magazine 24,03 (August 15, 1998). 
Madani (PNM, National Madani/Civil Society Financing ${ }^{129}$ ) on June 1, 1999, as a stateowned company that focuses on supporting the micro/small and middle enterprises. In practice, PNM's operations were linked with the vast network of Baitul Maal Wattamwil (Islamic cooperatives) connected to ICMI-affiliated Dompet Dhuafa.

Habibie's presidency could be described as the "period of institutionalization" for the Islamic economy movement because it was during this period that the basic institutional framework of an Islamic economy was established. At the least, there were three laws that significantly affected the development of the Islamic economy movement: Law No. 10/1998 on Banking, Law No. 23/1999 on Indonesia's Central Bank (Bank Indonesia), and Law No. 38/1999 on Zakat.

Law No. 10/1998 on Banking was issued to amend the 1992 law on banking. In the revised law, the term Islamic Bank (Bank Syariah) was mentioned explicitly, providing a strong legal basis for the development of Islamic banking and finance. This statute also provided a legal basis for the expansion of services provided by Islamic banks. Furthermore, it allowed the formerly prohibited dual banking system to be instituted and allowed interest-based banks to include Islamic banking units. Law No. 23/1999 on Indonesia's Central Bank (Bank Indonesia) mentioned that the Central Bank's monetary policies could include shari'a-based measures. Law No. 38/1999 on Zakat provided the legal basis for the establishment of non-governmental zakat management institutions (known as LAZ, or Lembaga Amil Zakat) and the government's zakat management institutions (known as $\mathrm{BAZ}$, or Badan Amil Zakat). Several other institutions were also born: the BI's team for research and development concerning the Islamic bank in Indonesia was initiated-this would prove to be the embryo for BI's Directorate for Islamic Banking; the National Agency for Zakat Management (Badan Amil Zakat Nasional, BAZNAS); and the state-owned corporation for supporting microfinance, the Permodalan Nasional Madani (PNM). The MUI also established Dewan Syariah Nasional Majelis Ulama Indonesia (Indonesia Islamic Scholars Council's National Shari'a Council, or DSN-MUI) in February 1999 as the highest authority for issuing fatwa regarding Islamic banking. ${ }^{130}$

These laws and institutions did not emerge from out of the blue. They were the results of lengthy, tiring negotiation processes among different stakeholders, including the Islamic economy movement advocates, business actors, members of Indonesia's House of Representatives (Dewan Perwakilan Rakyat, DPR), and different government bodies, such as the Ministry of Finance and Ministry of Religion (which often had different opinions).

\footnotetext{
129 "Masyarakat Madani" is the concept that was popularized by Nurcholis Madjid to translate "Civil Society." This term had been popular among ICMI circles and thus was used as the name of PNM. However, the name was never translated into English. In the English version of its website, the company name is still written as "PT Permodalan Nasional Madani," probably because of the difficulty of translating the name in a clear way. See http: / / www.pnm.co.id/ read/1/Corporate-Profile, accessed March 11, 2013.

${ }^{130}$ Islamic banks were obliged to have their own Shari'a Supervisory Body (DPS, Dewan Pengawas Syariah) to monitor their compliance with Islamic law. However, it is not uncommon for different scholars to have different views of the same issue. Thus, members of the MUI saw the need to set up a single authority to oversee compliance.
} 
Realizing that their time might be short, the activists struggled to put their agenda into the laws before the Habibie presidency was over. According to Saefuddin, they "lobbied different stakeholders day and night for around four months" to promote their agenda and ask that it be accommodated in the new law on banking. ${ }^{\mid 31}$ Members of Forum Zakat also worked hard to have their interests taken into account in the proposed law on zakat. The team consulted intensively with the Ministry of Religion. Didin Hafidhuddin was the leader of the team. ${ }^{132}$

It should be noted that the success of these activists was not due entirely to their own efforts. Habibie's presidency did significantly affect the government's stance because many ICMI leaders were appointed as top officials, but, in addition, bureaucrats from the related state institutions found that their own interests converged with the agenda of the Islamic economy movement. The BI established a specific team in April 1999 to conduct research on Islamic banking and supported the explicit inclusion of Islamic banking in the new law on banking. Bureaucrats from the Ministry of Religion were also eager to have their agenda recognized in the law on zakat. Their interests sometimes aligned with, and at other times diverged from, the interests of the Islamic economy movement. For example, while both the ICMI activists and the Ministry of Religion agreed that Indonesia needed a legal framework to regulate the management of zakat by LAZ and BAZ, they strongly disagreed on the role of the state. The Ministry of Religion wanted more authority for the state, while the Forum Zakat wanted more independence for the non-governmental zakat institutions (LAZs). There was also a triangular debate among the Ministry of Finance and Forum Zakat and the Ministry of Religion on the relationship between zakat and tax. ${ }^{133}$ Understanding that their opportunities to affect the laws were limited because the Habibie presidency would end soon, these parties finally compromised. Several unsettled points were carried over for later consideration. ${ }^{134}$

\section{After Habibie (1999-2012)}

While clearly Habibie's presidency and ICMI's prominence during his tenure were pivotal for the development of the Islamic economy in Indonesia, the bitter end of Habibie's reign and the rapid decline of the ICMI did not automatically mean the movement would also decline. Many activists were afraid that the new government, led by Abdurrahman Wahid, would harm the development of an Islamic economy, but it turned out that they were wrong to fear the transition, for the growth of the Islamic economy project in Indonesia was not disrupted by the rise of Wahid. Though he had been known for his critical attitude towards Islamic banking and the ICMI in the 1990s, President Wahid did not interfere in the growth of Islamic banking and other Islamic economy project initiatives. For example, the BI introduced the Islamic inter-bank

\footnotetext{
${ }^{131}$ Interview with A. M. Saefuddin, September 16, 2011.

${ }^{132}$ Interview with Didin Hafidhuddin, August 14, 2011. Didin Hafidhuddin is now serving as the chairman of the National Agency for Zakat Management (Badan Amil Zakat Nasional, BAZNAS).

${ }^{133}$ Interview with Rohadi Abdul Fattah, the director of Zakat Empowerment Directorate, Ministry of Religion, September 21, 2011.

${ }^{134}$ Interview with Didin Hafidhuddin, August 14, 2011. Interview with Irfan Syauqi Beik, September 9 , 2011.
} 
money market (Pasar Uang Antar Bank Syariah, or PUAS) in 2000 to support the growth of the Islamic banking industry, and Wahid did not oppose that initiative.

When Abdurrahman Wahid was replaced by Megawati Sukarnoputri from the secular Indonesian Democratic Party-Struggle (PDIP, Partai Demokrasi IndonesiaPerjuangan) following a political upheaval in 2001, the Islamic economy advocates once again felt anxious, yet during Megawati's presidency, from 2001 until 2004, Islamic banking and other initiatives of the Islamic economy project grew steadily. Megawati was not personally involved in either supporting or blocking it. The government's response to the Islamic economy project was shaped by the Central Bank of Indonesia (BI) and other related government institutions.

In the year 2002, the BI issued a regulation on Islamic banking units through BI regulation No. 4/1/PBI/2002. This regulation significantly fostered the growth of Islamic banking in Indonesia by providing the legal basis for the conversion of conventional banks into Islamic banks, conversion of conventional bank branches into Islamic bank branches, conversion of conventional banks' cash offices to Islamic banks' cash offices, establishment of an Islamic sub-branch within a branch of a conventional bank, and establishment of an Islamic banking unit within a branch of a conventional bank. It was also during Megawati's presidency, in 2003, that the BI decided to elevate the Islamic Banking Bureau and redefine it as the more powerful Directorate of Islamic Banking in response to the growing industry. In 2004, a law on wakaf was issued. This initiative actually came from the Megawati-led government, with the Ministry of Religion playing the central role. ${ }^{135}$

During Yudhoyono's presidency (2004-09, 2009-present), several pieces of legislation advocated by the Islamic economy movement were successfully enacted. These laws were Law No. 19/2008 on Sovereign Shari'a Securities (Surat Berharga Syariah Negara) and a specific Law on Islamic banking, Law No. 21/2008. Another related law was Law No. 23/2011 on Zakat. ${ }^{136}$ Like the two previous presidents, Yudhoyono was not directly involved in the details of the policy-making process concerned with Islamic economy-related policies. Nevertheless, many Islamic economy activists credited him for showing a willingness to attend a number of symbolic events celebrating their cause.

For example, President Yudhoyono attended the high-profile Islamic Economy Festival in 2008, at the Jakarta Convention Center's Plenary Hall. ${ }^{137}$ In January 2010, he hosted and launched the National Wakaf Movement (Gerakan Wakaf Nasional) in the presidential palace. On that occasion, he also symbolically gave a sum of 100 million IDRs as a monetary wakaf to be managed by the Indonesian Wakaf Agency (Badan

\footnotetext{
${ }^{135}$ In Indonesia's political system, the law could be proposed by the executive branch (president) and by the DPR.

${ }^{136}$ In the case of the Law on Zakat, many Islamic economy advocates, especially those in non-state zakat management institutions, were disappointed. Rather then reflecting their agenda and the interests of the general public, the new law on zakat reflects the interests of the Ministry of Religion. See "Undang-Undang Zakat Sulitkan Ummat Membayar Zakat" ("The (new) Zakat Law Created Difficulties for Muslims to Pay Zakat"), Republika Online, http://www.republika.co.id/berita/nasional/umum/11/10/27/1tpv33-uuzakat-sulitkan-umat-membayar-zakat, accessed July 5, 2012.

137 "Aset Perbankan Syariah Capai Rp. 32 Trilyun," Medina, http:/ / www.madina.co.id/index.php/ ekonomi/ 2325-aset-perbankan-syariah-capai-rp-32-trilyun.html, accessed on March 5, 2012.
} 
Wakaf Indonesia, BWI) ${ }^{138}$ Didin Hafidhuddin, the director of BAZNAS and an Islamic economy activist, also praised him for being willing to appear in the advertisements for the national zakat movement. ${ }^{139}$ In May 2010, President Yudhoyono attended the World Islamic Economy Forum. During the event, he stressed the importance of the cooperation between Muslim countries by advocating potential cooperation between the Middle Eastern petrodollar countries and Indonesia, which is rich in natural resources and human resources, and is also a growing market. ${ }^{140}$

Since Yudhoyono holds the highest executive authority, especially in Indonesia, where political messages are often conveyed through highly contextualized symbolic communication, his presence at these events was an important sign of the government's positive response to the development of the Islamic economy in Indonesia.

\section{Growth of the Islamic Economic Industry}

In addition to the state, the business sector played an important role in driving the post-New Order development of the Islamic economy project in Indonesia, particularly in the field of Islamic banking and finance.

Until 1999, the BMI was the only Islamic bank in Indonesia. There was an ongoing debate among directors of the bank, and also among the supporters of the Islamic economy, concerning whether the BMI should keep this monopoly. One of the reasons for arguing to stop this monopoly was the fact that when the BMI once faced a liquidity problem, it was forced to go to the "inter-bank money market" (PUAB, or Pasar Uang Antar Bank) and borrow money from the so-called "conventional" banks. ${ }^{141}$ However, it seemed unlikely that another Islamic bank would be born due to financial reasons (banks need a lot of money to start, and not many business actors were willing to invest their money in the establishment of an Islamic bank) and the still unclear regulatory framework. Interest-based banks were also prohibited from participating in the Islamic banking business because dual-system banking was still not allowed. The industry was not growing.

After the 1997 crisis, the BI started to endorse "Islamic banking."The new law on banking, issued during Habibie's presidency and also supported by the BI, provided a more favorable environment for Islamic banking. As part of the banking-sector's reconstruction process, business actors and banks were encouraged to open and support Islamic banking or Islamic Banking Units (Unit Usaha Syariah, UUS) as a way to diversify the banking sector.

\footnotetext{
138 "Wakaf Uang: Raksasa yang Masih Tidur" (Monetary Wakaf: A Sleeping Giant), Republika Daily, June $11,2010$.

${ }^{139}$ Interview with Didin Hafidhuddin, the Chairman of BAZNAS, August 14, 2011.

140 "SBY Hadiri Forum Ekonomi Islam Dunia di Kuala Lumpur" (SBY Attended the World Islamic Economic Forum in Kuala Lumpur), TVOneNews, http: / / nasional.tvonenews.tv/ berita/view/39268/ 2010/05/19/sby_hadiri_forum_ekonomi_islam_dunia_di_kuala_lumpur.tvOne, accessed on March 5, 2012.

${ }^{141}$ Interview with Aries Muftie, September 12, 2011.
} 
Another important measure taken by the Central Bank to save financial institutions damaged by the economic crisis was to merge them. One result of the mergers became Indonesia's second Islamic bank, the Bank Syariah Mandiri (BSM), founded on September 8, 1999, which commenced operations on November 1, 1999. ${ }^{142}$

The establishment of PT Bank Syariah Mandiri, owned by the powerful Bank Mandiri, marked the emergence of the Islamic economy as an industry. Before this point, the BMI was very much an idealistic project, which was accommodated by the state. After 1999, however, significant funds and investment started to enter the arena. For example, in 2001 the Indonesian tycoon Chairul Tanjung bought PT Bank Umum Tugu and converted it into an Islamic bank named Bank Syariah Mega, which started to operate in 2004. ${ }^{143}$ The alumni of BMI, such as Adiwarman Karim and Syafii Antonio, played a significant role by helping many business actors set up Islamic banks and other financial institutions.

The BI referred to the growth of Islamic banking from 1991 to 2008 as "impressive." The assets of Islamic banks had grown by a factor of twenty-seven during the last decade, developing from a 1.79 trillion IDR industry in year 2000 to a 49.6 trillion IDR industry by the year 2008 , with an annual asset growth of 46.3 percent. ${ }^{144}$ This level of growth is higher than the average growth of Islamic banking throughout Southeast Asia, including in Malaysia, which has been considered a center for the world's Islamic banking and finance sectors. ${ }^{145}$

The network of Islamic banks, including Islamic commercial banks (Bank Umum Syariah), Islamic Banking Units, and Islamic rural banks (Bank Pembiayaan Rakyat Syariah), was also growing. In 2005, the total number of offices (combined) was 550 units. In 2011, that number reached 2,101 units. ${ }^{146}$ The latest Islamic banking statistics, published in August 2012, showed that the number had reached 2,460 units. ${ }^{147}$ In 2006, the BI issued Peraturan Bank Indonesia No. 8/3/PBI/2006 (later revised by PBI No. 9/7/PBI/2007), which allowed "Office Channeling." Based on this regulation, a conventional bank can host the Islamic banking services of its Islamic bank unit. For example, a BNI Syariah "channel" could be opened in a BNI (conventional) office. The number of "channels" grew rapidly, from 456 in 2007 to 1,195 in $2008 .{ }^{148}$ The number of

\footnotetext{
${ }^{142}$ In early 1999, Bank Susila Bhakti (BSB) merged with several other crisis-affected banks. At around the same period, the government merged Bank Dagang Negara, Bank Bumi Daya, Bank Exim, and Bapindo into a new bank, named PT Bank Mandiri (Persero), on July 31, 1999. PT Bank Mandiri was granted the majority ownership of BSB and BSB was then transformed into Bank Syariah Mandiri. See "The History of BSM," at http: / / www.syariahmandiri.co.id/ category/info-perusahaan/profil-perusahaan/sejarah/, accessed January 4, 2011.

143 "A Brief Profile of Bank Syariah Mega," at http:/ / www.bsmi.co.id/ Profil-SekilasBSMI.php, accessed January 4, 2011.

${ }^{144}$ Halim Alamsyah (Deputy Governor of BI), "Perkembangan dan Prospek Perbankan Syariah Indonesia" (The Development and Prospect of Indonesia's Islamic Banking)," http: / / www.bi/go/id/nr/rdonlyres/ 91B91B56449-C5EA-4B6C-B03E-600863889853/25987/PerkembanganProspekPerbankanSyariahIndonesia MEA201.pdf, accessed on July 14, 2012. Also see Bank of Indonesia, Perkembangan Impresif $i-B$ (ai-bi) Perbankan Syariah (Jakarta: Bank of Indonesia, 2009).

${ }^{145}$ Bank of Indonesia, Perkembangan Impresif i-B (ai-bi) Perbankan Syariah (Jakarta: Bank of Indonesia, 2009). For simple statistics, see http: / / www.syariahmandiri.co.id/ category / edukasi-syariah /

${ }^{146}$ Bank of Indonesia, Statistik Perbankan Islam 2011 (December) (Jakarta: BI, 2011).

${ }^{147}$ Bank of Indonesia, Statistik Perbankan Islam 2012 (August) (Jakarta: BI, 2012).

148 Ibid.
} 
workers in Islamic banks also grew from around six thousand workers in 2005 to around 25,000 in 2011. ${ }^{149}$

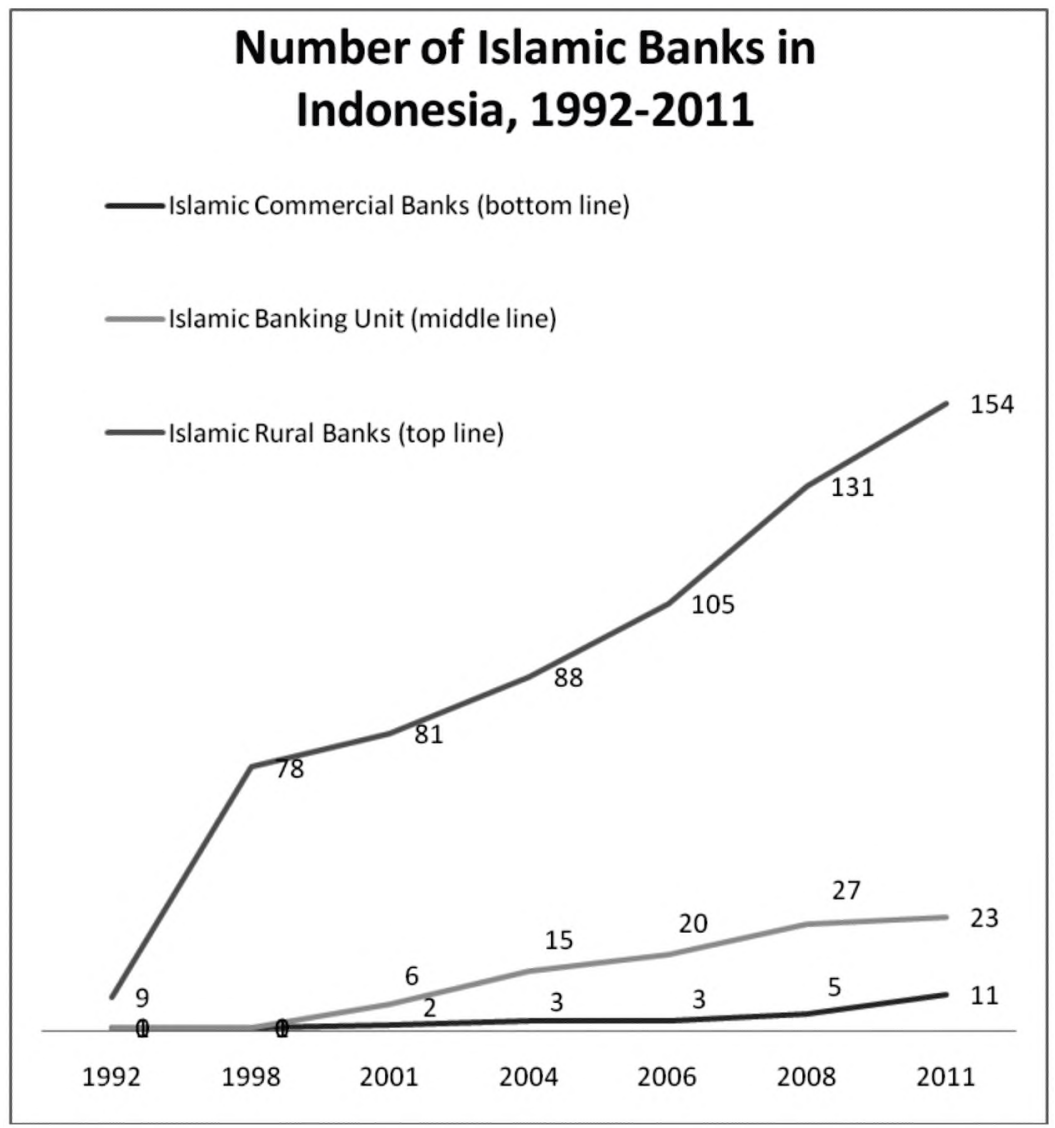

Number of Islamic banks in Indonesia, 1992-2011 150

The development of the Islamic economy in the banking sector spurred growth in other sectors. The MUI issued Fatwa DSN No. 37/DSN-MUI/X/2002 on the Islamic Inter-bank Money Market (Pasar Uang Antar Bank sesuai Syariah, PUAS). ${ }^{151}$ In the insurance and reinsurance sector, Islamic insurance was also growing. Annual growth was estimated at 35 percent, with 50 percent asset growth. ${ }^{152}$ In 2004, PT Reindo Syariah Unit (PT Reasuransi Internasional Indonesia) was founded as the first Islamic Reinsurance institution in Indonesia. ${ }^{153}$

The Islamic capital market has also been growing since the Jakarta Islamic Index opened in 2000. Indonesia's Islamic capital market was launched in 2003. Following the increased demand, the Indonesian Capital Market and Financial Institutions

\footnotetext{
${ }^{149} \mathrm{Tbid}$.

${ }^{150}$ Ibid.

${ }^{151}$ PEBS FEUI, Indonesia's Shari'ah Economic Outlook 2011, p. 56.

${ }^{152}$ Ibid., p. 27.

${ }^{153}$ Ibid., p. 31.
} 
Supervisory Agency (Badan Pengawas Pasar Modal dan Lembaga Keuangan, BAPEPAM LK) responded to the development by including Islamic bonds and financial certificates in the Indonesia Capital Market Master Plan (2005). The supervisory body also issued several specific regulations on the matter, such as Peraturan BAPEPAM-LK No. IX.A.14 (2006) and Peraturan BAPEPAM-LK No. II.K.1 and IX.A.13 (2009). It also issued an Islamic securities list (Daftar Efek Syariah) in 2007. ${ }^{154}$

\section{Growing Support in Society}

The growing Islamic economy industry and the supportive attitude of the government contributed to the strengthening of support for the Islamic economy movement from various actors within society. In the early 1990s, the MUI still acknowledged that there were differences among Muslim scholars regarding the prohibition of interest. In 2003, the MUI issued a fatwa that strongly declared interest to be usury and thus prohibited transactions involving interest for Muslims. Muhammadiyah, Indonesia's second largest Muslim organization, issued a similar fatwa in 2006, and in 2010 identified this interpretation as the official position of Muhammadiyah. These developments reinforced one another: as the Islamic economic movement gained a stronger footing in society, willing participation in its many outlets contributed to the further expansion of the industry.

The growth of the industry also inevitably gave Islamic business associations a stronger bargaining position relative to the state. Islamic business associations, such as ASBISINDO (Asosiasi Bank Syariah Indonesia, Association of Islamic Banks in Indonesia), ABSINDO (Asosiasi Baitul Maal wat Tamwil Se-Indonesia, Association of Baitul Maal wat Tamwil in Indonesia), Islamic Banking Compartment Perbanas (Islamic Banking Compartment of the Indonesian Banks Association), and INKOPSYAH (Induk Koperasi Syariah, Association of Islamic Cooperatives), were playing an important role in advocating for their interests. For example, ASBISINDO effectively pressed the BI finally to propose a specific law on Islamic banking, which was approved by the government and the DPR in 2008.

Following the decline of the ICMI, MES came to be the most important organization coordinating the Islamic economy movement. MES was established on March 26, 2001, in Jakarta, and grew rapidly, acting as a hub for various stakeholders in the industry, including state officials, academics, business persons, and supporters of the movement. It has three main objectives: to promote the Islamic economy; to create awareness in society about the Islamic economy; and to develop educational programs concerned with the Islamic economy. Since 2008, Muliaman Hadad, of the $\mathrm{BI}$, has been the chairman of MES.

Academic institutions have also been crucial to the recent development of an Islamic economy. The growth of the industry created a high demand for experts on Islamic economics. From the early 2000s, prestigious academic institutions such as University of Indonesia, Trisakti University, Bogor Institute of Agriculture, Indonesian Islamic University, and Airlangga University started to offer courses on Islamic economics, and some universities even created departments offering a degree in

${ }^{154}$ Ibid., pp. 43-54. 
Islamic economics. In addition, institutions of higher education that specialize in Islamic economics emerged, such as STEI (Sekolah Tinggi Ekonomi Islam, School for Islamic Economics) Tazkia, STEI Yogyakarta, and SEBI (Shari'a Economics and Banking Institute). ${ }^{155}$

One interesting development that is probably unique to Indonesia is the birth and development of the student organization FOSSEI (Forum Silaturahim Studi Ekonomi Islam, Communication Forum for Study of the Islamic Economy), founded in 2000, which has strongly shaped and helped define the characteristics of Indonesia's Islamic economy movement. ${ }^{156}$ In its Articles of Association, FOSSEI declared that its function included "Sebagai wadah aktualisasi mahasiswa peduli ekonomi Islam yang berbasis intelektual dan pergerakan" (" ... a platform for actualization of students who supported the Islamic economy which is based upon intellectualism and a social movement"). ${ }^{157}$ With its network, which spans the archipelago, FOSSEI became an efficient support base for the movement, supplying human resources to the industry, committing supporters to advocate for the Islamic economy movement, and helping develop Islamic economics as a science. The activists in FOSSEI often call each other "pejuang ekonomi Islam" (fighters for the Islamic economy) or "pejuang ekonomi Robbani" ("warriors of the God-guided economy"). The activists have proudly claimed that Indonesia's FOSSEI is the only student organization in the world that is specifically dedicated to the Islamic economy movement. ${ }^{158}$

\section{Convergence and Contestations}

The involvement of different actors in society, the state, and business communities has been significant for the development of the Islamic economy in Indonesia. ${ }^{159}$ However, conflicting interests among these different sets of players have inevitably led to complications. The actors have basically agreed on the need to support the Islamic economy project, but they have different motivations and different ideas about its optimal direction.

Idealists in the movement have seriously considered Islamizing Indonesia's entire economic system. This sort of radical change was certainly not desired by actors within the state, who have supported the Islamic economy movement because they see that its development can contribute positively to the current national economic system. But they do not want to eliminate the current system.

\footnotetext{
${ }^{155}$ Interview with Muhammad, Director of Sekolah Tinggi Ekonomi Islam (STEI) Yogyakarta, August 27, 2011.

${ }^{156}$ Interview with FOSSEI activists, Adithya Rangga Yogatama (Yogyakarta's Gajah Mada University student) and Imam Punarko (State University of Jakarta student, presidium of FOSSEI), August 6, 2011.

${ }^{157}$ FOSSEI, Articles of Association (Anggaran Dasar/Anggaran Rumah Tangga), Article 9 (1) of the Anggaran Rumah Tangga.

${ }^{158}$ Interview with FOSSEI activists, Adithya Rangga Yogatama and Imam Punarko, August 6, 2011.

${ }^{159}$ It should also be noted that the distinctions and divisions between the various groups-the movement's advocates and society, state, and business actors-are not clear-cut. Many Islamic economic movement activists have become prominent business actors and state officials. The prestigious Central Bank of Indonesia, for example, now offers career opportunities for people with Islamic economics and religious studies backgrounds. Many former FOSSEI activists, or those with a close relationship to FOSSEI, are entering the BI and other state institutions and are thus able to support an Islamic economy within the state institution.
} 
The BI saw that the growth of the Islamic banking sector reinforced the stability of Indonesia's banking system. In various documents, BI representatives have stated that their institution strongly supports the development of Islamic banking in Indonesia for two main reasons: 1) there is a real demand in society for shari'a-compliant banking services; and 2) the distinct characteristics of Islamic banking, which distinguish it from its conventional counterparts, will benefit the whole national banking system. According to the $\mathrm{BI}$, the development of Islamic banking will strengthen the resilience of Indonesia's national banking system and positively contribute to national economic growth. ${ }^{160}$ Some officials in the Ministry of Finance, particularly those in the debt management office, recognized that a thriving Islamic economy could be an important financing tool for the government, and thus they started to think and learn about the development of Islamic instruments (including Surat Berharga Syariah Negara, or sukuk), beginning in the early 2000s. ${ }^{161}$ The growth of LAZs in the early half of the $2000 \mathrm{~s}$ made the Ministry of Religion realize that zakat and various types of religious philanthropies, such as infaq or wakaf, were huge businesses with potential transactions of over 37 trillion IDR per year (around US $\$ 4.1$ billion per year). ${ }^{162}$

Nascent conflicts between the parties that support the Islamic economy is further complicated by the prominence of profit-motivated business actors in driving the growth of Islamic banking and the finance industry. Most business actors are rational and interested in profiting from their investments. As Ventje Raharjo, managing director of the BRI Syariah Bank until 2011, has noted, the success of an Islamic bank should be indicated by its profit. ${ }^{163}$ However, he quickly added that, while the professional measure of an Islamic bank's success must be its profit, Islamic banks are different from their conventional counterparts because profit is not their only objective. Islamic banks must also take into account the empowerment of poor people (dhuafa).

The drive for profit is an important incentive for the growth of an Islamic economy, but also often problematic for both the state and the movement. The state often worries that if business actors, driven by profit-seeking ambitions, are allowed to function uncontrolled, they may damage not only the Islamic economy industry but also the whole national economy. Ali Sakti, a BI senior researcher, noted that "BI is often more Islamic than the Islamic banks" because some Islamic banks often simply copy the popular products offered by their interest-based counterparts and create an Islamic version of it. ${ }^{164}$ The popularity of this "reverse engineering" among Islamic banks also troubles the idealists in the movement, who view this as an example of how capitalism had successfully co-opted the Islamic economy project. ${ }^{165}$

\footnotetext{
${ }^{160}$ See Bank of Indonesia, Informasi Seputar Peningkatan Status Biro Perbankan Syariah (BPS) Menjadi Direktorat Perbankan Syariah (DPBS) (Jakarta: BI, 2003). See also Bank of Indonesia, Kebijakan Akselerasi Pengembangan Perbankan Syariah 2007-2008 (Jakarta: BI, 2007).

${ }^{161}$ Interview with officials from the Directorate for Shari'a Financing Policy, Slamet Prayitno and Masyhuri, September 20, 2011.

${ }^{162}$ Ishbir Fadly, head of the Subdirectorate of Zakat Management Institutions Empowerment, " Asumsi Potensi Zakat, Infaq dan Shodaqoh Per Tahun," document of the Ministry of Religion, July 7, 2011.

${ }^{163}$ Interview with Ventje Raharjo, Managing Director of PT BRI Syariah (2009-11), September 12, 2011.

${ }^{164}$ Interview with Ali Sakti, senior researcher at BI, August 11, 2011.

${ }^{165}$ Interview with Jusuf Wibisono and Banu Muhammad, activists and faculty members of the Faculty of Economy, University of Indonesia, August 12, 2011.
} 
While dealing with their internal conflicts, the Islamic economy movement activists, business actors, and related state institutions still have to maintain good connections with various external actors and organizations, such as MUI, Islamic organizations, and local ulama (Islamic scholars). Thus, rather than arguing over their differences, most of them are focusing on their convergence of interests.

Nevertheless, some conflicts do persist. Differing views among BI, business actors, MUI, and some Islamic economy movement activists regarding the governance of Islamic banking is a telling illustration. During the legislative debates over the 2008 Law for Islamic banking, the BI wanted to establish Komite Perbankan Syariah (an Islamic banking committee) within the BI structure with significant power to regulate the Islamic banking industry. However, this idea was not completely accepted by the business actors (who were influential in MES, the main platform for publicizing the movement) due to their worries that the BI would gain stronger control of the industry and thus limit its growth. MUI representatives were also not really fond of the idea because they worried that the KPS would take over their role (i.e., to issue fatwa regarding Islamic banking practices). Finally, the KPS was established under the BI structure, but with an unclear role, more like that of an advisory board, and it was not as powerful as it had been designed to be. Fatwa power stayed in the Dewan Syariah Nasional Majelis Ulama Indonesia (DSN-MUI). However, because the MUI was not a state body, it had no legal power. Thus, as before, the fatwa only served as an accepted agreement among the actors and would only become a law after the BI issued a regulation (Peraturan Bank Indonesia) based on that particular fatwa. Of course, theoretically, the BI could choose to ignore any fatwa that it did not agree should be legalized as a PBI. ${ }^{166}$ Because of its unclear position, the KPS was only effective for two years, from 2008 to 2010 .

To this day, some officials in the BI still find that the current governance of the Islamic banking industry is a little bit problematic. Formally, the guideline for the industry was set by the BI through BI regulations, or PBI. However, many PBIs came from fatwa declared by the DSN-MUI, because the BI representatives realized that scholars in the MUI had more authority to issue religious decrees than they did. The process of issuing a fatwa begins when an institution, usually an Islamic bank or other business institution, formally submits a request for a particular fatwa to the DSN-MUI, usually concerning the permissibility of a particular business practice. Following the request, the DSN-MUI then will conduct meetings to discuss the matter. It should be noted that all costs for the discussion process related to issuing a fatwa are borne by the institution that requested the fatwa. While the DSN-MUI members and the Islamic banks always insist that the DSN-MUI is independent when making a fatwa, and few individuals have come forward to criticize the process, some are worried that the process is unhealthy because there are many conflicts of interest. Even though the applicant who requests a fatwa has no direct say in the final decision, the applicant pays for the cost of the process and the exchange of money can lead to temptation. In addition, a number of DSN-MUI members hold positions as DPS members in many Islamic banks, so the opportunities for using influence, and money, to support requests

${ }^{166}$ Interview with Ali Sakti, senior researcher at BI, August 11, 2011. 
for fatwa are legion. ${ }^{167}$ Sometimes, financial institutions promised MUI a share of the profits, such as in the recent Golden Traders Indonesia Syariah case. ${ }^{168}$

Despite the tendency of the actors involved to sweep their differences under the carpet by not talking about them openly or avoiding direct criticism of each other, the tension between different parties does occasionally surface. A clear example of this was when the BI finally issued a moratorium to stop gold-pawning services by Islamic banks in December 2011. Even though the practice had been considered permissible by the DSN-MUI, with several qualifications and cautions, the BI had been worried about pawning since the beginning. They were afraid that the drive for profit could lead Islamic banks to focus more on the gold pawning business than on their core functions as intermediary institutions. ${ }^{169}$

In the zakat sector, the contestations between the movement and the state, and even between state units, do appear. The Ministry of Religion was aware of the development of zakat management institutions in Indonesia and acknowledged that the non-state zakat management institutions were doing well. However, at the same time, the ministry argued that the government take stronger control over the business to prevent "unwanted development," such as the mushrooming of unprofessional zakat institutions or the use of zakat for political purposes. ${ }^{170}$ The difference clearly appeared during the amendment process of the law of zakat, which finally granted stronger authority to the state through the new law on zakat (Law No. 23/2011). Ahmad Juwaini, the executive director of Dompet Dhuafa and a Chairman of Forum Zakat has argued that some points of the new law are worrisome. In his view, the new law has given the state too much authority regarding the establishment of LAZ and $\mathrm{BAZ}$ in regencies, the issuance of legal permission for the establishment of a non-state zakat management institution (LAZ), and even the authority to invoke sanctions for

\footnotetext{
${ }^{167}$ Interview with Ali Sakti, Senior Researcher at BI, August 11, 2011. Also from an interview with Ahmad Ifham Sholihin, Islamic banker at BNI Syariah and the author of several books on Islamic banking and finance, August 9, 2011.

${ }^{168}$ In March 2013, Golden Traders Indonesia Syariah (GTIS) was accused of investment swindling. GTIS's director, Michael Ong, a Malaysian, took the customers' money and vanished. Ong operated GTIS after getting permission from MUI in August 2011. During the process, Ong approached Aziddin, an ulama at MUI, and invited him to be a GTIS advisor. Ong promised that 10 percent of GTIS profit would be allocated for MUI. To convince Aziddin, Ong went so far as to say that he was interested in converting and becoming a Muslim and that he wished to marry a Muslim woman, and he even called Aziddin "father." "Kepolisian Mendata Korban Penipuan GTIS," Tempo Daily, March 6, 2013. While MUI quickly declared that they were also "victims" of the swindling, it exposes the vulnerability of the governance of Islamic banking and finance.

169 "Ada Bank Lakukan Pelanggaran, BI Akan Tetapkan Aturan Gadai Emas Syariah," Republika Daily, December 23, 2011. See also "Mencermati Rahn Emas pada Bank Syariah," http:/ / zonaekis.com/ mencermati-rahn-emas-pada-bank-syariah $/>$, accessed on January 10, 2012. Even though the moratorium was issued in December, the talks about it had already started when I visited the BI office in September 2011.

${ }^{170}$ Head of the Directorate of Zakat Empowerment, Ministry of Religion, Rohadi Abdul Fattah, "Kebijakan Nasional di Bidang Pengelolaan Zakat," document of the Ministry of Religion, September 2011. I gained similar information from an interview with Rohadi Abdul Fattah and Ishbir Fadly, head of the Subdirectorate of Zakat Management Institutions Empowerment, September 21, 2011. On the use or abuse of zakat for political purposes, the officials of the Ministry of Religion mentioned that some zakat management institutions are affiliated with particular political parties and thus the social aid from the zakat was often seen as the work of particular political parties
} 
zakat management institutions. ${ }^{171}$ Apart from this issue, there has been an ongoing debate between the movement, the Ministry of Religion, and the Ministry of Finance on the relationship between zakat and tax, in the form of a tax credit. ${ }^{172}$ Director General of Taxation of the Ministry of Finance, Tjiptardjo, criticized Forum Zakat by saying that "a tax credit [for zakat payers] will mean that the government subsidizes them. It is unfair that paying zakat [a religious obligation] is subsidized by the government. ${ }^{173}$ Finally, the government issued a regulation, not in the Law, allowing a person who pays zakat to claim it as a tax deduction. Zakat payers are eligible to deduct their zakat donations from their gross income (pendapatan brutto), thus reducing the amount of their taxable income. However, the Ministry of Finance rejected further concessions. ${ }^{174}$ The amended zakat bill was passed in 2011, but the debate continues.

\section{The Paradox of Growth: Integration and Fragmentation, Moderation, and Radicalization}

The appearance of Chinese-looking businessman in the 2008 television advertisement for i-B (Islamic Banking), described at the beginning of this essay, had a deep symbolic significance. As mentioned above, anti-Chinese sentiment, a local feature of politics in Indonesia stemming from Indonesia's political-economic situation, was present in the early development of Indonesia's Islamic economy movement. Close observation suggests that the advertisement illustrates the fact that Indonesia's Islamic movement itself is changing.

The involvement of various actors in society, state, and the business community has helped the growth of the Islamic economy and, at the same time, influenced its development. Despite frequent reference to the global discourse regarding an "Islamic economic system," in its early development the movement was colored by a strong local context. Movement advocates criticized the perceived unfair economic and development policies of the Suharto government, which were related to the New Order policy of enforcing the depoliticization of Islam in the 1970s and 1980s. Thus, the movement was strongly political and ideological.

When the state loosened its grip and allowed Islamic banking in the early 1990s, this did not mean the government accepted the proposal that an Islamic economy might replace the established national economic system. The state was merely acommodating the demand from assertive and influential Muslim groups due to the political shift in the regime.

\footnotetext{
171"Ahmad Juwaini: Empat Pasal Mencemaskan di UU Zakat 2011," at http:/ / www.dompetdhuafa.org. 2011/11/25/ahmad-juwaini-empat-pasal-mencemaskan-di-uu-zakat-2011/, accessed January 10, 2012.

${ }^{172}$ Head of the Directorate of Zakat Empowerment, Ministry of Religion, Rohadi Abdul Fattah, "Kebijakan Nasional di Bidang Pengelolaan Zakat," document of the Ministry of Religion, September 2011. Similar information gained from an interview with Rohadi Abdul Fattah and Ishbir Fadly, September 21, 2011.

${ }^{173}$ Ramdhania El Hida, "Tjiptardjo: Masa Bayar Zakat Disubsidi Orang Lain?," Detik Finance, August 27, 2010, at http: / / m.detik.com / read / 2010/08/27/100738/1429136/ 4/ tjiptardjo-masak-bayar-zakatdisubsidi-orang-lain?f9911013?topnews, accessed January 14, 2012.

${ }^{174}$ Government Regulation No. 60/2010. Forum Zakat insists that if zakat was a tax credit rather than a tax deduction, more people would be willing to pay zakat.
} 
The rise of the Islamic economy movement's patron, Habibie, to the presidency after the 1997 economic crisis created momentum for the movement, which advocates used to their advantage as they sought to institutionalize the Islamic economy project, particularly Islamic banking and finance and zakat. Furthermore, state institutions such as Bank Indonesia, the Ministry of Finance, and the Ministry of Religion saw the potential benefit of the Islamic economy project to their own institutional interests. Thus, instead of embracing an Islamic economic system to replace the established national economic system, the state tried to integrate the Islamic economy as a supporting element of the national economy. Since 1999, more and more business actors are playing an important role to strengthen this integration. For example, many Islamic banks are owned by persons who began their careers in interest-based banking and remain heavily invested in that sector.

The involvement of the state and business entrepreneurs helped to integrate Indonesia's Islamic economy movement into the global Islamic economy industry. In the 1980s, the movement had limited resources to connect with global institutions, including international organizations like the Islamic Development Bank and its Islamic Research and Training Institute (IRTI), international banking and finance institutions, and leading academic institutions. Following the establishment of BMI in 1991, BI officials started to build stronger connections with the IDB and IRTI and to learn from Islamic banking practices in various countries, including Singapore, the United Kingdom, the United States, and Iran. ${ }^{175}$ In the early 1990 s, four foreign Islamic banks, namely the Faisal Islamic Bank of Egypt, the Al Barakah of Saudi Arabia, Malaysian Islamic Bank (Bank Islam Malaysia) of Malaysia, and Daar Maal Al Islami of Switzerland, opened branches in Indonesia.

The integration between the national and global economy profoundly affected Indonesia's Islamic economy movement by making it more moderate and less political. Interestingly, this development was smooth because the movement saw that support from the state and business was essential for its growth.

For example, as part of its policy to support the growth of Islamic banking, the BI hired Hermawan Kartajaya, a marketing expert with a Catholic-Chinese background. Kartajaya was also asked by the Central Bank to become a member of Komite Perbankan Syariah (Islamic Banking Committee). ${ }^{176}$ While the revolutionary rhetoric that advocates changing the economic system entirely remains in the movement's discourse to some extent, the rhetoric of "coexistence" is also gaining popularity among Indonesia's Islamic economy activists. The integration into the national and global economy has tended to mitigate anti-Chinese sentiment. As Adiwarman Karim said, " ... to grow, the movement has to embrace different actors, including wealthy Chinese businessmen. The Islamic economy should be proven beneficial for all." ${ }^{177}$

The tolerant proposal that an Islamic economy should be beneficial for all, including non-Muslims, also appeared frequently in various MES documents. Rather

\footnotetext{
175 “Subarjo Joyosumarto: Pelopor Bank Mustahil di Indonesia," Jurnal Nasional Daily, October 11, 2011.

${ }^{176}$ Interview with Hermawan Kartajaya, founder of MarkPlus Inc. and member of the Komite Perbankan Syariah BI, 2008-10, August 11, 2011.

${ }^{177}$ Interview with Adiwarman Karim, founder and president director of Karim Business Consulting and one of the chairmen of Indonesian Society for Islamic Economy, September 14, 2011.
} 
than pressing for an (unrealistic) top-down reform of the economic system, many activists prefer to seek the "conscious and incremental" realization of the Islamic economy.

The discourse on capitalism is also changing. Of course, the activists still criticize capitalism as an unjust economic system. However, compared to conditions in the 1980 s and 1990s, when Islamic economy discourse was often mixed with the anticapitalist discourse justifying a "people's economy," the movement's contemporary rhetoric has grown more tolerant of capitalism as the movement has become increasingly integrated into the national and global economy. Wahyu Dwi Agung, Chairman of the ASBISINDO from 1998 through 2005, said "What's wrong in being a Muslim capitalist [kapitalis Islam]?" ${ }^{178}$ While it is unclear exactly what he meant by the phrase "Muslim capitalist," it illustrates that the term "capitalism" no longer represents an ultimate evil.

While the involvement of various actors within the state and the business sector has helped integrate Indonesia's Islamic economy movement into the national and global economy, thereby moderating it, at the same time it has disintegrated the movement and created more ideological groups that call for "real" Islamization of the economic system. The growth of the Islamic economy industry has spawned, in various degrees, optimism, pessimism, and even skepticism among the movement's supporters.

In her article on BMT, Minako Sakai noted the disappointment of some pioneers and activists of the Islamic economy movement, who were unhappy with the evolution of the growing Islamic economy industry. Many were disappointed by the tendency of Islamic banks to set a high priority on earning profits for their shareholders rather than on taking risks for the sake of supporting micro, small, and medium-sized enterprises. ${ }^{7 / 4}$ Some criticized the way Islamic banking and financial institutions are now becoming less and less "Islamic" as they become more oriented to making a profit. In Saefuddin's words: "Many do not care about empowering the weak anymore." ${ }^{180)}$

Despite their reservations, most movement activists have not expressed their criticisms publicly. In public, figures like Saefuddin and Amin Aziz are still loyal supporters of the Islamic economy movement. As Aries Muftie said, "If you could not get a 100 percent Islamic economy, do not throw away the 80 percent or even 40 percent Islamic economy." ${ }^{181}$

Ideological groups have been born from the disappointments related to the perceived un-Islamic practices of the Islamic economy industry. In Bandung, an important site in the history of the movement's early development, an ideological campaign calling for the "real Islamization" of the economic system has gained ground since approximately 2008. Its proponents not only condemn interest as usury, they also

\footnotetext{
${ }^{178}$ Interview with Wahyu Dwi Agung, the chairman of ASBISINDO, 1998-2005, September 13, 2011.

${ }^{179}$ Minako Sakai, "Community Development through Islamic Microfinance: Serving the Financial Needs of the Poor in a Viable Way," pp. 267-85.

${ }^{180}$ Interview with A.M. Saefuddin, September16, 2011.

${ }^{181}$ Interview with Aries Muftie, September 12, 2011.
} 
argue that fiat money (which is still used by Islamic banks) is also considered usury and thus prohibited. They also claim that all banks, including the Islamic banks, are against Islam. The real Islamic economy, according to the new movement, should be based on the use of dinar and dirham (gold and silver money). The activists call the Islamic economy a "deception" perpetrated by the West. Dinar First, one of the main organizations supporting this movement, has frequently criticized Islamic banks in such terms as "Islam-cloaked loan-sharks" directed by "greedy global oligarchs." 182 This "Dinar Movement" is now growing in several major cities, such as Bandung, Jakarta, Depok, and Yogyakarta. For now, mainstream Islamic economy movement activists do not consider this "Dinar First" challenge to be much of a threat-yet.

\section{Concluding Remarks: More Gains, More Pains?}

What does the future hold for Indonesia's Islamic economy movement? Most Islamic economy movement activists are optimistic. In 2011, MES published Roadmap Ekonomi Syariah Indonesia (Indonesia's Islamic Economy Roadmap), which covered different achievement targets of the Islamic economy project until $2020{ }^{183}$ The general vision for 2020 sounded ambitious: "Sistem Ekonomi Indonesia telah Menerapkan Sistem Ekonomi Syariah" ("The Indonesian Economic System applies the Islamic Economic System.") The roadmap set a target: sometime, in 2017-19, the society will ask that Indonesia's economic system become entirely Islamic ("Pemimpin, ummat, dan masyarakat meminta ekonomi syariah menjadi sistem ekonomi Indonesia" ). ${ }^{184}$

However, if we look at the breakdowns of the achievement targets, the roadmap turns out to be more modest than one might judge at first glance (even though it still appears overly optimistic and ambitious if we consider the size of the Islamic economy industry today relative to the size of the Indonesian economy). For example, the roadmap does not envision an Islamic Central Bank, but rather recommends the appointment of a specific Deputy Governor of BI responsible to deal specifically with Islamic banking. ${ }^{185}$ It also does not envision that all laws related to the economy be revised in compliance with the Islamic economic system, but "only" envisions that all necessary regulations related to the Islamic economy project would be confirmed in the legal system as laws. ${ }^{186}$ It does not suggest replacing the banking and financial system with an Islamic banking and financial system, but proposes that the market share of Islamic banking and financial system should reach 20 percent of the whole economy. ${ }^{187}$

\footnotetext{
182 Tweets by @DinarFirst, December 25, 2011. See also articles at www.dinarfirst.org or www.islam hariini.wordpress.com

${ }^{183}$ It should be noted, though, that MES's Indonesia's Islamic Economy Roadmap was accepted as a common roadmap by all of its members and other actors related to the Islamic economy project. For example, BI, despite the fact that its high-ranking official was the chairman of MES, published its own Grand Strategy for Islamic Banking, which differs from the roadmap in certain items.

${ }^{184}$ Pengurus Pusat Masyarakat Ekonomi Syariah, Roadmap Ekonomi Syariah Indonesia [Indonesia's Islamic Economy Roadmap] (Jakarta: MES, 2011), pp. 7-9.

185 Ibid., p. 10.

${ }^{186}$ Ibid., p. 9.

${ }^{187}$ Ibid., p. 11.
} 
While the numbers might be overly optimistic, ${ }^{188}$ it may well be true that an Islamic economy will continue to grow. Consultants such as Karim Business Consulting are still busy preparing to establish new Islamic banks or Islamic banking units. The state continues to be interested in developing sovereign shari'a securities for government financing. More and more academic institutions are opening classes for teaching Islamic economics.

Nevertheless, the gains might not be without pains. So far, many disagreements among the relevant actors have been swept under the carpet. Despite their uneasiness regarding the current governance of Islamic banking, BI's Directorate of Islamic Banking remains generally silent in order to avoid disturbing the growth of the Islamic banking industry. Despite their criticisms of current business practices in the Islamic economy industry, senior activists such as Saefuddin remain silent in public. Yet as the industry expands and the number of persons involved increases, this silence might be broken soon.

As we have seen, the involvement of various actors within civil society (MUI, ICMI), the state (BI, Ministry of Finance, Ministry of Religion), and the business sector has helped the Islamic economy grow as a dynamic industry. The role of the state and business actors, who supported the movement for different reasons, was to integrate the Islamic economy industry into the national economic system and into the global economy. However, the interactions and negotiations among these actors during the process have inevitably resulted in at least two contradictions. First, the interactions and negotiations are integrating the movement into the national and global economy but are also fragmenting the movement. Second, integration has created a moderating effect (e.g., the rise of "coexistence" rhetoric, more inclusive characteristics, the fading of anti-Chinese sentiment), while at the same time giving birth to more ideological groups (i.e., the Dinar Movement). These contradictions are the pains of growing up.

The symptoms of these growing pains have recently begun to surface. As already mentioned, BI finally issued a moratorium to stop gold pawning services by Islamic banks in December 2011, after it had delayed for several months. While the mainstream Islamic economy movement activists do not consider the Dinar Movement as a threat, the campaign that criticizes Islamic banking and finance for its capitalist practices is gaining strength in places where the Islamic economy movement had its roots, such as in Bandung, Bogor, and Jakarta. Self-criticisms from Islamic economy movement activists and debates among them are also becoming more common and more public, especially with the help of social media such as Twitter and Facebook.

With more actors becoming involved in the Islamic economy industry, the struggle to find convergence of interests among them will be more challenging. The industry will continue to grow, but there will be more pains coming from the struggle to balance idealism and pragmatism. For Indonesia's Islamic economy movement, the road ahead might not be as smooth as in the MES Roadmap.

${ }^{188}$ Using ambitious numbers could be seen as a strategy to boost morale of their supporters. Thus, it is not always important to assess whether this number is "realistic." 


\section{List of Acronyms}

\begin{tabular}{|c|c|}
\hline ABSINDO & $\begin{array}{l}\text { Asosiasi Baitul Maal wat Tamwil Se-Indonesia, Association of Baitul Maal } \\
\text { wat Tamwil in Indonesia }\end{array}$ \\
\hline ASBISINDO & Asosiasi Bank Syariah Indonesia, Association of Islamic Banks in Indonesia \\
\hline BAZ & Badan Amil Zakat, Zakat Management Agencies \\
\hline BAZNAS & Badan Amil Zakat Nasional, the National Agency for Zakat Management \\
\hline BAPEPAM-LK & $\begin{array}{l}\text { Badan Pengawas Pasar Modal dan Lembaga Keuangan, Indonesian Capital } \\
\text { Market and Financial Institutions Supervisory Agency }\end{array}$ \\
\hline BI & Bank Indonesia, Central Bank of Indonesia \\
\hline BMI & Bank Muamalat Indonesia \\
\hline $\mathrm{BMT}$ & Baitul Maal Wat Tamwil, Islamic Savings and Credit Cooperative \\
\hline BPRS & Bank Pembiayaan Rakyat Syariah, Islamic Rural Banks \\
\hline BUS & Bank Umum Syariah, Islamic Commercial Banks \\
\hline DD & Dompet Dhuafa, The Poor's Pocket \\
\hline DPS & Direktorat Perbankan Syariah (of BI), Directorate of Islamic Banking \\
\hline DSN-MUI & $\begin{array}{l}\text { Dewan Syariah Nasional Majelis Ulama Indonesia, Indonesia's Council of } \\
\text { Islamic Scholars, National Shari'a Council }\end{array}$ \\
\hline FKPI & $\begin{array}{l}\text { Forum Komunikasi Pembangunan Indonesia, Communication Forum for } \\
\text { the Development of Indonesia }\end{array}$ \\
\hline FOSSEI & $\begin{array}{l}\text { Forum Silaturahim Studi Ekonomi Islam, Communication Forum for } \\
\text { the Study of the Islamic Economy }\end{array}$ \\
\hline FOZ & Forum Zakat, Zakat Forum \\
\hline IAEI & $\begin{array}{l}\text { Ikatan Ahli Ekonomi Islam, [Indonesian] Islamic Economics Scholars } \\
\text { Association }\end{array}$ \\
\hline ICMI & $\begin{array}{l}\text { Ikatan Cendekiawan Muslim Indonesia, Association of Indonesian Muslim } \\
\text { Intellectuals }\end{array}$ \\
\hline IDB & Islamic Development Bank \\
\hline INKOPSYAH & Induk Koperasi Syariah, Association of Islamic Cooperatives \\
\hline KPS & Komite Perbankan Syariah, Islamic Banking Committee (of BI) \\
\hline $\mathrm{LAZ}$ & Lembaga Amil Zakat, Society-based Zakat Management Institution \\
\hline MES & Masyarakat Ekonomi Islam, [Indonesian] Islamic Economic Society \\
\hline PKES & $\begin{array}{l}\text { Pusat Komunikasi Ekonomi Syariah, Communication Center for the Islamic } \\
\text { Economy }\end{array}$ \\
\hline PNM & $\begin{array}{l}\text { Permodalan Nasional Madani, state-owned corporation for supporting } \\
\text { microfinance }\end{array}$ \\
\hline
\end{tabular}


PPA

Pusat Pengembangan Agribisnis, Center for Agribusiness Development

SBSN Surat Berharga Syariah Negara, Sovereign Shari'a Securities

UUS

Unit Usaha Syariah, Islamic banking units 